\title{
The Preservative Efficacy of Antimicrobial Proteins and Metabolites from Microorganisms, Animals and Plants as Potential Alternative to Chemical Food Preservation: A Review
}

\author{
Betemariam Kebede \\ Ethiopian Institute of Agricultural Research, National Agricultural Biotechnology Research Center, Microbial \\ Biotechnology Research Program
}

\begin{abstract}
Food is a source of nutrients and energy for humans and animals. Though food is assumed to be safe for consumption, it is highly susceptible for microbial contamination responsible for health risks and economic loss. This requires the mechanism that keep food fresh and safe for extended period of time. So far, in human history various physical and chemical methods have been employed to extend shelf life. Unfortunately, these methods are found to have a lot of drawbacks that pose problem on the quality and safety of the product beyond consumer need. Biological preservation using microbial, plant and animal derived metabolites and antimicrobial peptides has recently got considerable attention as the safest way of extending shelf life of food with no adverse effects on product quality. The antimicrobial efficiency of antimicrobial peptides and metabolites have been found to significantly inhibit the growth of potent food borne pathogens and spoilage microorganisms. However, the efficacy of biological antimicrobial agents for food preservation is potentiated by combined application with fewer chemical preservatives with smart formulation of a series of hurdle called hurdle technology. In this review, reports on the efficacy of antimicrobial peptides and metabolites of microbes, plants and animals in preserving various food stuffs are well reviewed during independent application and as part of hurdle system.
\end{abstract}

Keywords: Biological preservation, Food, Food quality, Hurdle technology, Microbial/plant/animal metabolites DOI: $10.7176 /$ FSQM/87-05

Publication date:May $31^{\text {st }} 2019$

\section{Introduction}

Nature has given many types of foods to mankind. Everybody expects that the food they eat is wholesome, and safe for consumption (Pal et al., 2015). But it is prone to microbial contamination depending on the safety measure taken by food handlers. While growing on food for self-perpetuation, microbes release compounds as metabolic by products, which can have positive and negative impact on food quality. Some of the metabolites improve the organoleptic characteristics of food, whereas others make food to lose quality standards, the status where food is supposed to be spoiled or poisoned (Jay, 2000). A variety of microorganisms can grow in food with conducive environment causing spoilage, disease and intoxication to food. Among the most potent food borne pathogens of food industry concern are Listeria monocytogenes, Staphylococcus aureus, Escherichia coli 0157:H7, Salmonella spp., Campylobacter spp., Clostridium botulinum and Bacillus cereus, and are responsible for the most widely reported food borne outbreaks. Especially, Listeria monocytogenes, the causative agent of food borne listeriosis, is a frequent pathogen with universal distribution and resistant to low $\mathrm{pH}$, refrigeration temperature and high salt treatment up on prolonged storage in refrigerator (Bastos et al., 2011).

Nowadays, food is transported across the world as part of globalization; food globalization, during which food is subjected to spoilage and poisoning, food safety risks, that makes efficient preservation method critically important (Lineback et al., 2008). Industries have been employing a variety of techniques to enhance the shelf life and quality of food. Chemical and physical methods are among the most common methods to keep food fresh. However, chemical preservatives like nitrites have been tested for their toxicity, and physical treatments such as high processing temperature results deterioration of nutritional components of food (Salem, 2012). On the other hand, consumer demand for fresh and minimally processed food with or without chemical additives is alarmingly increasing through time. Hence, the most critical challenge facing the food industry is providing clients with fresh, safe and minimally processed products. Therefore, preservation process, as indicated in legislation, should contain a combination of mild heat treatment and low chemical preservatives. However, some pathogenic and spoiling microorganisms have been found to resists this mode of preservation, which implies a more efficient and legally approved method has to be developed (Jeevaratnam et al., 2005).

Several methods have traditionally been employed to cope up with hindrances related to shelf life enhancement since past history times, knowingly or unknowingly, by mankind, among which: smoking, salting, drying, high temperature treatment, spontaneous fermentation and aging are common (Zeuthen and BoghSokenson, 2003). Although most traditional ways are effective in altering the niche of spoilage and pathogenic microbes, they have drawbacks of changing organoleptic properties and nutritional composition of food being treated (Nath et al., 2014). 
Currently, for sufficient preservation, traditional methods are being substituted by combined application of modern and effective technologies with natural antimicrobial compounds such as bacteriocins, organic acids and plant and animal derived metabolites with less deleterious impact on stability and microbial safety of food products in shelf life extension, and to produce food product that harmonize consumer interests and safety standards. Likewise, as natural method bio-preservation of food has been given due attention by most manufacturers to extend the shelf life and to improve food safety, which is defined as the use of non-pathogenic micro/organisms and/or their metabolites to hamper the growth of or reduce spoilage and pathogenic microbes in food to assure the safety and extended shelf life in a well-controlled and predictive manner (Salem, 2012). Thus, bio-preservation is suggested as a natural and ecofriendly food preservation system. As a result of a growing public health concern in the application of chemical additives and adverse physical treatment, biopreservation become active research area to substitute risky preservative techniques (Parada et al., 2007 and Nath et al., 2014). This review will discuss the efficacy of potential preservatives: microbes and/or their metabolites, plant and animal products, which help industries to produce food with reduced or chemical additive free and microbiologically safe products towards replacing chemical preservatives.

\section{Efficacy of microbial derived preservatives}

Food preservation had begun when the sailors travelling long distance used to carry fermented fruits and vegetable with them so as to ensure long term preservation. The practice of food fermentation was used in Babylon 5000 years ago by consuming fermented drinks and bread in Egypt 1500 BC. Since then, mankind knew the role of fermentation in food processing and the first scientist is French chemist Louis Pasteur in describing the role of yeast in wine processing, what he called fermentation (Mani, 2018). Nowadays, fermentation is one of the food preservation mechanisms both in small scale and large-scale food processing.

Fermentation is a common biotechnological process for the preservation of food products with desirable properties such as extended shelf-life and good organoleptic properties. Considerable food preservation by fermentation is achieved through the breakdown of complex compounds that results in the formation of a variety of inhibitory metabolites like organic acids (lactic acid, acetic acid, formic acid, and propionic acid), reuterin, bacteriocins, alcohols, gases accompanied by a decrease in water activity. Moreover, fermentation improve food safety via the inhibition of pathogens and increase the nutritional value and organoleptic properties by producing compounds responsible for flavor and aroma (Ray and Joshi, 2014 and Nath et al, 2014).

Fermentation can be induced or spontaneous. The latter is a natural fermentation process where the fermentation is spontaneously taken place by natural inhabitant microorganisms, while the former is initiated by the addition of a single or combination of known microorganisms. Microbes can deliberately be added to food either to initiate fermentation as starter culture or to inhibit the growth of undesirable microorganisms and to get rid of unwanted substances in the food like toxins and anti-nutritional factors, as protective culture. The most common microorganisms found in fermented food are bacteria, yeast and mold. Among bacteria frequently isolated from fermented food are lactic acid bacteria which are Gram-positive cocci or rods, non-aerobic but aerotolerant, able to ferment carbohydrates for energy and lactic acid production whereas Saccharomyces cerevisiae is the most dominant yeast in food. Lactic acid bacteria due to their safe history of use and over dominant in fermented food as well as their physiological features such as substrate utilization, metabolic capabilities and probiotic properties are honored generally regarded as safe organisms (GRAS). The presence of consortia of microorganisms and their metabolic products formed during fermentation, make fermentation a promising way of food preservation. Amongst the metabolic products synthesized by microorganisms that attracted food industries and researchers as a potential natural preservative are bacteriocins (Ray and Joshi, 2014).

Garc1'a-Bayona et al. (2017) defined bacteriocins as ribosomally synthesized peptides or proteins with antimicrobial activity against related or other species that compute for similar ecological niche. As reviewed by Nath et al. (2014) bacteriocins differ from therapeutic antibiotics in being protein in nature which can be digested by proteolytic enzymes, and ribosomally synthesized; easy to manipulate in order to improve their intensity and spectra of action. Although bacteriocin are produced by both gram negative and gram-positive bacteria, those from gram positive bacteria are widely studied and well elucidated. Particularly, bacteriocins produced by lactic acid bacteria are given considerable attention since they are produced by GRAS graded and frequently outnumbering group of bacteria in fermented food for many years.

Karpiński and Szkaradkiewicz (2013) classified bacteriocins into four classes based on molecular weight, presence of the YGNGVXC motif, disulphide bridges, activity towards Listeria sp., and sensitivity to temperature. Class I: consists of lantibiotics or thermostable peptides of molecular weight below $5 \mathrm{kDa}$ and undergo posttranscriptional modification with typical amino acids such as lantionine (Lan), methyllantionine (MeLan), dehydroalanine (Dha), dehydrobutyrine (Dhb), or D-alanine (D-Ala). Moreover, they are further sub divided as type A and type B sub groups with specific structure and function. The former is elongated and acts by permeabilization of cytoplasmic membrane of susceptible cells, whereas the latter is globular and variable 
manner of action. Class I bacteriocins are known to contain extensively used bacteriocins by food industries; nisin produced by Lactococcus lactis. Class II non-lantibiotic bacteriocins, which contain non-lantionine and are thermostable bacteriocins of molecular weight below $10 \mathrm{kDa}$ with no posttranslational modification. They are highly diversified and sub divided into four sub groups: a, b, c, and d. Class III: includes bacteriocins of molecular weight above $30 \mathrm{kDa}$ and are thermolabile. Class III are sub divided into two sub groups: bacteriolytic enzymes which facilitate inactivation of sensitive strains by cell lysis, for instance, lysostaphin of Staphylococcus aureus and enterolysins of Enterococcus faecalis, and the non-lytic antimicrobial proteins. Class IV includes bacteriocins that need presence of a lipid portion or a carbohydrate portion for their optimum action. Because bacteriocins are highly diversified and differ in their antimicrobial efficiency, a number of researchers all over the world studied their efficacy in extending shelf life and safety of different food.

Bacteriocins and bacteriocin producing microbes can be applied in food preservation in many ways: (1) Inoculation of food with bacteriogenic LAB; (2) Addition of purified or semi-purified bacteriocins as food preservatives and (3) a product previously fermented by bacteriocin producing strain as an ingredient in food processing. However, the efficiency of bacteriocins is affected by factors such as development of resistance by pathogens; inadequate environmental conditions for better biological activity; higher retention of the bacteriocin molecules by food system components (e.g. fat) and inactivation by other additives. Besides, salt concentration, food ingredient, solubility and the extent of uniform distribution of bacteriocins in food matrix are additional factors to be considered while dealing with bacteriocin efficiency in food preservation. By taking the above factors and conditions into account, several intensive investigations have been done as reviewed here under (Jeevaratnam et al., 2005 and Nath et al., 2014).

\subsection{Efficacy of bacteriocin in meat and meat product preservation}

As revised by Woraprayote et al. (2016) the most widely applied bacteriocins belong to class I and IIa due to their target specificity which are biochemically and genetically characterized. Although nisin is the only commercially produced and officially accepted bacteriocin for use in meat, poultry, ready-to-eat meat products, sausage casing, pediocin is among the most studied and employed in meat and meat products. In addition, pediocin is used to control the growth of L. monocytogenes; the most recurrent pathogen in ready to eat meat products. Besides, irrespective of the difference in anti-listeria activity depending on the producing or indicator strains, the sample preparation method, and the bacteriocin assay conditions, pediocin has higher sensitivity to $L$. monocytogenes than nisin.

According to Woraprayote et al. (2016) bacteriocin are used in meat and meat products in three major ways: direct inoculation of bacteriocin producing LAB as protective or starter culture; direct application of cell free supernatant as food additive and purified or partially purified bacteriocin as packaging.

\subsubsection{Direct inoculation of bacteriogenic $L A B$}

Because purification of bacteriocins need more investment on technology and infrastructure, application of purified bacteriocin is economically infeasible. Hence, using bacteriogenic lactic acid bacteria as either starter culture or protective culture is paramount. Starter cultures release metabolites responsible for the organoleptic property of meat products and produce antimicrobial peptides, whereas protective culture produce antimicrobial peptides including bacteriocins to hamper the growth of undesirable microorganism with no deleterious impact on products. Nevertheless, there are some issues to be considered while applying bacteriogenic LAB: compatibility problem between bacteriocin active LAB and other starter culture consortia for meat product processing; unwanted byproducts might be produced by a mono culture LAB in meat fermentation; efficient protection may not be attained by bacteriogenic LAB protective culture as a result of unoptimized growth condition generated from food matrix ( Woraprayote et al. (2016).

The role of LAB in improving the quality of fermented meat products and safety by controlling spoilage and pathogenic microorganisms, especially, L. monocytogenes, have been intensively studied. Strains of LAB species, naturally occur in a vast range of ready-to- eat food including meat, secret bacteriocins active against Listeria spp., nisin of Lactococcus lactis and pediocin of Pediococcus acidilactici, are the most well-known. However, Lactobacillus sakei are the most important and interesting as being the high competent species in meat environment. Moreover, Pediococcus acidilactici is the common species used as starter culture in meat industry (Kongo et al, 2013). When bacteriocin producing LAB are used as starter culture in meat, the CFU count of listeria is reduced during the course of fermentation and get higher at the onset of fermentation. But, bacteriocin activity get higher when cell adsorbed $(4500-2000 \mathrm{AU} / \mathrm{g})$ bacteriocin is used than bacteriocin producing strains (2000-1000AU/g) as reported by Kouakou et al. (2008). Although starter cultures are very crucial in standardizing product quality and assure product safety by changing the prevailing conditions to unfavorable for pathogenic and spoilage microbes, a number of potent pathogens Escherichia coli, Listeria monocytogenes and Yersinia enterocolitica are able to survive regardless of storage condition. Therefore, bio-preservation of meat products by starter culture should be coupled with some hurdle technology for maximum preservation (Kongo et al., 2013). 
As summarized by Budde et al. (2003) lactic acid bacteria are among the dominant microbes in nonfermented products, such as vacuum-packed, making the product sensory fresh throughout the storage period. From the wide spread LAB in nonfermented meat products, some are found to inhibit L. monocytogenes in confirming them as promising candidate for protective culture. The reduction of L. monocytogenes, the regular pathogen in meat products, is possible up to $90 \%$ in raw and below detectable level in cooked pork inoculated with L. curvatus CWBI- B28mt after two weeks of storage at $4{ }^{\circ} \mathrm{C}$, although the pathogen regrowth was observed at the end of two weeks. Since bacteriocins are sensitive to proteolytic enzymes, the high cellular proteolytic activity, both intra and extracellular, results in a remarkable decrease in bacteriocin activity that paves a way for the rapid regrowth of the pathogen (Kouakou et al., 2008).

The bacteriogenic strain Lactobacillus curvatus CRL705 which grew from $1.2 \mathrm{X} 10^{6}$ to $3.2 \cdot \mathrm{X} 10^{8} \mathrm{CFU}$ after 36 days of incubation at $2^{\circ} \mathrm{C}$, while reducing the growth of meat spoilage bacteria $B$. thermosphacta from $6.4 \times 10^{2}$ to $2.1 \times 10^{1} \mathrm{CFU}$ after 14 days of incubation and which continued up to the end of incubation period. This result implies Lactobacillus curvatus CRL705 is an efficient protective culture to inhibit Listeria innocua and Brochothrix thermosphacta in vacuum-packaged meat (Castellano and Vignolo, 2006). A significant control of L. monocytogenes was reported by Jacobsen et al. (2003) in cooked meat products by Leuconostoc carnosum while storing at 5 and $10{ }^{\circ} \mathrm{C}$ for four weeks. In addition, Leuconostoc spp. are reported as safe and potential protective culture against E. coli O157:H7 in ground meat (Koo et al., 2015).

2.1.2. Direct application of bacteriocins to meat product preservation

Bacteriocins are added to meat and meat products for effective control of spoilage and pathogenic microorganisms. Bacteriocins are applied in different forms: cell free supernatant, semi-purified and purified forms in the case when cells in protective or starter culture are unable to produce enough antimicrobial peptides or proteins against undesired microbes (Woraprayote et al., 2016).

The application of a semi-purified enterocin from $E$. faecium strain in the raw (minced pork meat and raw chicken breasts) and cooked meat products (pa`te' and cooked ham) considerably inhibited Listeria innocua at different degree. Especially, in minced pork meat Listeria innocua from less than $10 \mathrm{MPN} / \mathrm{g}$ up to $48 \mathrm{CFU} / \mathrm{g}$ and up to $6 \times 10^{5} \mathrm{CFU} / \mathrm{cm} 2$ in chicken breasts at abusive storage temperature, $7^{\circ} \mathrm{C}$ for 6 to 7 days. The hydrophobic nature of enterocin contribute a lot in sufficient hinderance of Listeria innocua in minced pork that possess high fat content. Similarly, enterocin inhibit the growth of Listeria innocua under 3MPN/g of pa 'te' treated with 4,800 AU/g (Aymerich et al., 2000). A semi purified bacteriocin, pentocin 31-1, derived from bacterial isolates of meat is successful in decreasing the potential contaminants of packaged pork meat; L. monocytogenes and Pseudomonas fluorescence, and extend the shelf life up to 15 days at chilling temperature, when applied at 80 AU/g concentration (Zhang et al., 2010).

The study by Nieto-Lonzalo et al. (2006) on the control of Listeria monocytogenes and Clostridia perfringens growth by bacteriocin produced by Pediococcus acidilactici applied on Spanish raw meat. The result revealed bacteriostatic effect on Clostridia perfringens when the meat was treated with $5000 \mathrm{BU} / \mathrm{g}$ with $0.5 \mathrm{log}$ cycle reduction at $4^{\circ} \mathrm{C}$ storage temperature. The treatment with 1000 and $5000 \mathrm{BU} / \mathrm{g}$ reduced Listeria monocytogenes growth by 2 and $3 \log$ cycle at $15{ }^{\circ} \mathrm{C}$, respectively. The efficiency of bacteriocin produced by Pediococcus acidilactici, pediocin PA-1, is more effective against Listeria monocytogen than Clostridia perfringens. Likewise, anti- listerial efficacy of sakaci from Lactobacillus ccurvatus ACU-1 was studied by Rivas et al. (2014) using three sets of experiments on cooked meat surfaces: in situ bacteriocin production system, cell free supernatant and combined system of cell free supernatant and bacteriocin producing stain. A considerable reduction of listerial growth was seen by the former system as a result of effective adsorption of sakaci Q to the target cells. Unlike in situ bacteriocin production, antibacterial activity of cell free supernatant reduced after the third week of storage, whereas the combined system of bacteriocinogenic strain and cell free supernatant revealed a pronounced effect on listeria at the end of the third week. Moreover, food borne pathogen due to cross contamination from grinding of ground meat was efficiently cope up with supernatant of Leuconostoc isolate DGB 1040 (Koo et al., 2015).

Abee et al. (1995) showed the ability of nisin in preventing spore outgrowth and retarding vegetative cells of Bacillus spp. and Clostridium spp. Because of favorable conditions in vacuum-package meat products, LAB grow aggressively and dominate the microflora and tend to result in unwanted condition for the product: undesirable flavor, low $\mathrm{pH}$, milky exudates, gas production, swelling of the pack and discoloration (Kalschne et al., 2014). To control this situation, Kalschne et al. (2014) studied the potential of nisin to overcome the effective of LAB in ham and found that a successful growth inhibition using $0.013 \%$ and $0.007 \%$ was achieved. This result is much pronounced when nisin is applied with heat treatment that kill gram positive bacteria resistant to nisin. The main limitations to nisin in meat products are related to the low solubility, the possibility of enzymatic destruction, and the inefficient inhibition of several important pathogenic or spoilage microorganisms (Da Costa et al, 2019). According to Bastos and Ceotto(2011) review, nisin is a well-known, GRAS graded and an e ective bacteriocidal agent against Gram-positive bacteria, including strains of Streptococcus spp., Staphylococcus spp. and Listeria spp. Even though fermented foods are supposed to be pathogen free, Listeria 
spp. are confirmed to survive and even grow in fermented foods with raw materials possessing the organism. Furthermore, nisin has been studied and elucidated for the efficacy in inhibiting the most notorious pathogens and spoiling microbes in meat and meat products to assure extended shelf life, while maintaining nutritional quality.

A remarkable inhibition of Listeria innocua and Brochothrix thermosphacta was reported by Castellano and Vignolo (2006) when both the protective culture of Lactobacillus curvatus CRL705 and a purified bacteriocin lactocin 705 are applied in vacuum packaged meat during the 36 days of storage at $2{ }^{\circ} \mathrm{C}$. The study of Aymerich et al. (2000) evaluated the potential of a semi-purified enterocin in inhibiting the growth of Listeria innocua at abusive storage temperature in five different meat products. Since the growth rate of the producer strain $E$. faecium CTC492 and bacteriocin production capacity is considerably reduced by refrigeration temperatures and essential ingredients of fermented sausage, it is highly recommended to use purified or semi purified bacteriocins. In this regard, enteriocin of E. faecium CTC492 significantly reduced the growth rate of Listeria innocua by $3.61 \log$ CFU/g in espetec (slightly fermented sausage) at $221 \mathrm{AU} / \mathrm{g}$ enterocin concentration after 5 days of storage, a 7.98-log CFU/ g reduction in cooked ham with 4,800 AU/g enterocin at the end of the 37 days of storage at $7^{\circ} \mathrm{C}$ while with 4,800 AU/g of enterocins was able to keep Listeria under $3 \mathrm{MPN} / \mathrm{g}$ in pa te. Growth of Listeria was not observed ( $3 \mathrm{MPN} / \mathrm{g}$ ) after 6 days of storage at $7{ }^{\circ} \mathrm{C}$ when 1,600 AU/g is used.

\subsection{Efficacy of bacteriocin in sea food fish preservation}

Seafood borne diseases accounts for $10-20 \%$ food borne outbreaks as a result of pathogenic bacteria including Vibrio, Listeria monocytogenes and histaminogen. According to Ghanbari and Mansooreh (2013) pathogenic bacteria related to seafood products belong to either of three general groups: 1) Bacteria (indigenous bacteria) that belong to the natural microflora of fish (Clostridium botulinum, pathogenic Vibrio spp., Aeromonas hydrophila); 2) Enteric bacteria (non-indigenous bacteria) that are present due to faecal contamination (Salmonella spp., Shigella spp., pathogenic Escherichia coli, Staphylococcus aureus); and 3) bacterial contamination during processing, storage, or preparation for consumption (Bacillus cereus, Listeria monocytogenes, Staphylococcus aureus, Clostridium perfringens, Clostridium botulinum, Salmonella spp.).

Seafoods are highly susceptible to spoilage bacteria producing off-odors and are risky food stuff groups. Because the existing processing steps of seafoods are not strong enough to reduce or limit the growth of pathogenic and spoilage bacteria, global interest in looking for efficient technique such as bio protection to enhance the quality and safety of seafood is increasing for the last few years. Lactic acid bacteria are among the most outnumbering microorganisms during storage under vacuum or modified atmosphere and have also been tested for the control of potent pathogenic bacteria like Listeria monocytogenes at the laboratory scale in cold smoked salmon and in a lesser extent in other products with successful results, so far (Pilet and Leroi, 2011).

A number of research reports indicate an intensive research has been done to minimize seafood quality and safety related risks to consumers worldwide. There have been different attempts to preserve seafood products using biological agents and metabolites from microorganisms, while keeping the growing interest of consumers in minimally processed and microbiologically stable seafood stuff. The notorious pathogen encounter in seafood is Listeria monocytogenes that attributes to its ability to grow at low $\mathrm{pH}$, high salt concentration and low storage temperature, and many of the research focus on controlling this pathogen using microbial derived metabolites or microorganisms themselves. The most widely studied microbial metabolites in this regard is crude or purified bacteriocins especially nisin, approved by many countries in the world as biological preservative. However, in addition to nisin many bacteriocins have been tested to perform well in the case where nisin is not successful. Earlier in 1995 Enarsson and Lauzon studied the preservation of shrimp using crud and purified nisin Z, carnocin UI49, and bavaricin A. The shelf life of shrimp subjected to the control treatment was found to be 10 days. Carnocin UI49 did not extend the shelf life, while crude bavaricin A (a cell-free supernatant of Lactobacillus bavaricus MI 401) resulted in a shelf life of 16 days, as opposed to 31 days with nisin $\mathrm{Z}$ for both its crude and purified forms. The benzoate-sorbate solution preserved the brined shrimp for the whole storage period (59 days). In the control, carnocin UI49, and crude bavaricin A treatments, a gram-positive flora dominated towards the end of the storage period. In contrast, in nisin $\mathrm{Z}$ treatment a gram-negative flora were more pronounced.

Effective preservation of cold smoked salmon was achieved for 7 days by sakacin $\mathrm{P}$ by preventing the growth of L. monocytogenes, where as a remarkable decrease in L. monocytogenes load was observed with the addition of nisin. The application of a purified sakacin $\mathrm{P}$ and the producing strain L. sakei Lb790 significantly reduced L. monocytogenes count from $3.5 \times 10^{3} \mathrm{cfu} / \mathrm{g}$ to $50 \mathrm{cfu} / \mathrm{g}$ over the period of 28 days of storage at abusive temperature, $10^{\circ} \mathrm{C}$. The most important finding of this study is the efficiency of the bacteriocin sakacin $\mathrm{P}$ increases with decreasing in $\mathrm{pH}$ and at elevated level of salt which is conducive for L. monocytogenes growth. In addition, the fat content of cold smoked salmon is lower than the fat concentration at which sacacin $\mathrm{P}$ is successfully inhibited the growth of L. monocytogenes. This work put sakacin P and producing strain system among potential system for efficient preservation of cold smoked salmon and similar seafood products (katla et al., 2001). Correspondingly, Behnam et al. (2015) reported that nisin treated fish revealed less and acceptable 
biochemical (peroxide value, thiobarbituric acid-index, $\mathrm{pH}$ and total volatile nitrogen) and bacteriological (total viable counts, psychrotrophic viable counts, and lactic acid bacteria) up to 16 days of storage at $4{ }^{\circ} \mathrm{C}$ compared to those treated without nisin. Furthermore, FAs composition analysis indicated that the presence of nisin preserved nutritional quality of fish lipid, so that nisin treated samples contained higher percentage $(p>0.05)$ of essential FAs such as eicosapentaenoic acid and docosahexaenoic acid. This study concluded that treatment of the vacuum packaged rainbow trout with nisin resulted in improvement of quality and extension of shelf life of fish from 12 to 16 days at $4{ }^{\circ} \mathrm{C}$.

Bacteriocins, nisin (lantibiotic) or class IIa bacteriocins, have transitory effect on food industry important microorganisms including Listeria monocytogenes as a result of addition of bacteriocin followed by regrowth of target cell. This can arise from inadequate application of nisin to the products or development of resistant cells. The work of Bouttefroy and Milliere (2000) showed a marked decrease in the frequency of nisin resistance $L$. monocytogenes variants up to $10^{-9}$ which is largely depend on salt concentration ( $\mathrm{NaCl}, \mathrm{K} 2 \mathrm{HPO}$ ). Synergy of nisin/curvaticin 13 exhibited a completed death of Listeria monocytogenes upon continuous addition of nisin/curvaticin 13 that ensure the control of regrowth and spontaneous resistant variants of cells after certain period of storage. Therefore, the amount of bacteriocin of interest and best working physicochemical situation must be considered for maximum attainment of bio-preservation at storage conditions.

Reports from various research imply the potential inhibition of pathogenic and spoilage microorganisms in seafood products specifically Listeria spp. by bacteriocinogenic lactic acid bacteria, when they are used as protective culture. The study by Weiss and Hammes (2006) depicted that the use of bacteriogenic culture as inoculum is more efficient than the application of a culture supernatant with antagonistic activity as tested on salmon juice. Inoculation of L. sakei LTH4122 and L. sakei LTH5754 reduced Listeria strain count by 2 log units within $24 \mathrm{~h}$ of incubation at $5{ }^{\circ} \mathrm{C}$. Besides, cultures of LAB did not bring about any negative impact on the sensory qualities of cold smoked salmon products. This make bacteriogenic LAB a promising option to improved safety of seafood. A similar research by Yamazaki et al. (2003) inhibition of Listeria monocytogenes in cold-smoked salmon by Carnobacterium piscicola CS526 results in the reduction of pathogen below detection level, which rely on the level of inoculum. The L. monocytogenes population decreased to below the detection limit (50CFU/g) after 7 days at 4 and $12{ }^{\circ} \mathrm{C}$ when the initial inoculum levels of C. piscicola CS526 were $10{ }^{6}$ and after 21 days at $4{ }^{\circ} \mathrm{C}$ and 12 days at $12{ }^{\circ} \mathrm{C}$ when the initial inoculum levels of C. piscicola CS526 was $10^{4}$.

\subsection{Efficacy of bacteriocins in fruit and vegetable preservation}

2.3.1. Fresh produce

Fresh produces are prone to contamination from various sources: manure, irrigation water, insects, and during harvesting and other process operations as a result of poor agricultural practices and brought about outbreaks. A number of bacteriocin preparations (nisin, pediocin, or enterocin AS-48) have been assayed for their efficacy in combating food borne pathogens and toxicogenic bacteria: Listeria monocytogenes, Bacillus cereus, and Bacillus weihenstephanensis, Escherichia coli, Salmonella and other enterobacteria, on the surfaces of fresh-cut vegetables and on sprouted seeds. Bacteriocins have been tested for potential role in getting rid of pathogenic bacteria from the whole surfaces so as to avoid transmission to processed fruit and decrease survival on sliced fruit surfaces up on storage (Gálvez et al., 2014).

Studies on the reduction of pathogenic microorganisms in fruit and vegetable indicate a limited success. A pH dependent effect of enterocin AS-48 was studied by Molinos et al. (2008) where L. monocytogenes showed no growth in most of the fruits stored at $6^{\circ} \mathrm{C}$ like raspberries $(\mathrm{pH} \mathrm{3.3)}$, peer $(\mathrm{pH} 4.81)$ and kiwi $(\mathrm{pH} 3.49)$, while it multiplied on sliced melon $(\mathrm{pH} 4.82)$ and sliced watermelon ( $\mathrm{pH} 5.74)$ up to the level or beyond 6 log CFU/g. Besides, a good capability of survival of Listeria was observed in most of the fruits tested with the exception of fruits of lower $\mathrm{pH}$ : blackberries ( $\mathrm{pH} 2.50)$ and sliced strawberries ( $\mathrm{pH} 2.70)$. A higher efficiency of enterocin AS-48 against Listeria monocytogenes was observed in a washing treatment in fruits with higher $\mathrm{pH}$ (such as sliced melon and watermelon), as well as in fruit samples stored under refrigeration at $6^{\circ} \mathrm{C}$ compared with those stored at 15 or $22^{\circ} \mathrm{C}$. Hence, washing treatment of ready- to- eat fruits, with high $\mathrm{pH}$, stored at refrigerator temperature before consumption will reduce the initial viable cells of Listeria enhancing the microbiological safety of fruits. Enterocin AS-48 in synergy with p-hydroxybenzoic acid methyl ester (PHBME) (80 lg/g) and with 2-nitropropanol (40 lg/g) against Salmonella enterica serovar Enteritidis CECT 4300 in Russian salad exhibited a reduction in concentration of viable Salmonella from 4.75 to $4.27 \mathrm{log} \mathrm{CFU} / \mathrm{g}$ down to the limit of detection for 7 days at $10^{\circ} \mathrm{C}$ (Molinos et al., 2009a). Similarly, Molinos et al. (2009b) enhanced Enterocin AS$48(30 \mu \mathrm{g} / \mathrm{g})$ antilisterial activity by essential oils in Russian salad after one-week storage at $10^{\circ} \mathrm{C}$.

Leverentz et al. (2003) treated fresh-cut produce with nisin showed the survival of Listeria monocytogenes populations and increased only slightly on fresh-cut red delicious apples stored at $10{ }^{\circ} \mathrm{C}$, but increased significantly on fresh-cut honeydew melons stored at $10^{\circ} \mathrm{C}$ over 7 days. A $25 \mu \mathrm{g} / \mathrm{ml}$ nisin in combination with hydrogen peroxide $(1 \%)$, sodium lactate $(1 \%)$, and citric acid $(0.5 \%)$ (HPLNC) results in absence of both Escherichia coli $\mathrm{O} 157: \mathrm{H} 7$ and Listeria monocytogenes in fresh- cut melon after 7 days of storage at $5^{\circ} \mathrm{C}$, 
whereas at days 0 and 7 treatment with HPLNC significantly reduced the numbers of both pathogens by 3 to 4 $\mathrm{log} / \mathrm{cm}^{2}$ on the two types of whole melons (Ukuku et al., 2005). Olandunjoe et al. (2016) inoculated fresh-cut tomato with $10^{8} \mathrm{CFU} / \mathrm{ml}$ of Listeria monocytogenes ATCC 7644 to deal with the inhibitory efficacy of nisin of $5000 \mathrm{UI} / \mathrm{ml}$ alone or with organic salt sodium acetate $(5 \mathrm{~g} / 100 \mathrm{ml})$ or sodium citrate $(3 \mathrm{~g} / 100 \mathrm{ml})$ and $200 \mathrm{ppm}$ chlorine as control incubated at different temperature $\left(4,10\right.$ and $\left.25{ }^{\circ} \mathrm{C}\right)$ observed at $0,24,48$ and 72 hours for 10 days. Among the treatments the combination of nisin and organic salt significantly inhibited the pathogen than the control, chlorine.

\subsubsection{Fruit Juices and Drinks}

Bacteriocins are applied in fruit juices and drinks as best option for prolonged shelf life and microbiological safety. Bacteriocins confer an excellent preservation in fruit juice and drinks because of important features of the items: (1) improved diffusion of bacteriocin molecules (compared to solid substrates), (2) a low fat content in general, minimizing bacteriocin adsorption to hydrophobic food components, (3) an acidic $\mathrm{pH}$, which in general facilitates bacteriocin solubility and activity and (4), they usually contain organic acids and other bioactive molecules which may potentiate bacteriocin activity. Hence, bacteriocins are applied in fruit and drinks to inhibit endospore forming bacteria such as Alicyclobacillus acidoterrestris and thermophilic spore formers like Geobacillus stearothermophilus, bacteria responsible for ropiness that produce exopolysaccharide: Bacillus licheniformis, pediococci and lactobacilli (Gálvez et al., 2014).

Some studies have shown the possible scenario of inactivation of spore forming, thermophilic and acidophilic food industry important bacteria with the addition of different bacteriocins. The most widely studied bacteriocin, nisin is reported for effective preservation of fruit products such as juices, pulps and minimally processed fruits alone or in combination of thermal and non-thermal process technologies (Barbosa et al., 2016). The addition of $100 \mathrm{IU} / \mathrm{ml}$ nisin has completely inhibited the vegetative growth and spore outgrowth of the most frequent endospore forming spoiling bacterium Alicycolbacillus acidoterrestris in a pasteurized fruit juice at an abusive temperature $44{ }^{\circ} \mathrm{C}$ and storage temperature $25{ }^{\circ} \mathrm{C}$ with minimum inhibitory concentration of $5 \mathrm{IU} / \mathrm{ml}$ (Komitopoulou et al., 1999). Similarly, Walker and Phillips (2008) reported that the same effect of nisin at levels of 2.5-10 IU $/ \mathrm{ml}$ and storage temperature of $30^{\circ} \mathrm{C}$ on Alicycolbacillus acidoterrestris in fruit juice. Carvalho et al. (2006) demonstrated the inhibition of the growth of spore forming bacteria B. thuringiensis LMA09, B. cereus LMA19 and B. thuringiensis LMA65 below the detection level by bovicin HC5 (100 AU/ml). Bovicin HC5 has also showed bactericidal effect on the vegetative growth of Clostridium tyrobutyricum inoculated in mango pulp ( $\mathrm{pH} 4.0$ ) and reduced gas production by the strain during 10 days of incubation (Carvalho et al. 2007). A profound effect of nisin in combination with outer membrane permeabilizing treatments on enteric pathogens including $E$. coli and salmonella has been reported by many researchers. In apple juice a combined effect of nisin and cinnamon accelerated death of Salmonella typhimurium and E. coli O157:H7, enhancing the safety of the product. A substantial inactivation of Salmonella typhimurium by nisin and lysozyme was observed in orange juice than either nisin or lysozyme alone showing that bacteriocins are more effective in combination than when they are applied alone (G'alvez et al., 2008).

The bacteriocin enterocin AS-48 is among exhaustively studied bacteriocin produced by Enterococcus spp. According to Burgos et al. (2014) enterocin AS-48 seems a good candidate for application in bio-preservation of fruit juices. Addition of low enterocin AS-48 concentrations in juices artificially contaminated with vegetative cells as well as with endospores of $A$. acidoterrestris caused complete bacterial inactivation and afford protection for up to 14 days in freshly made orange and apple juices, and for up to 60 to 90 days in several commercial fruit juices under storage temperatures in the range of 4 to $37{ }^{\circ} \mathrm{C}$. The thermophilic spore former $G$. stearothermophilus could also be inactivated rapidly by enterocin AS-48 in coconut milk and coconut water by a low bacteriocin concentration of $1.75 \mu \mathrm{g} / \mathrm{mL}$. The antimicrobial efficacy of enterocin AS-48 against $B$. cereus LWL1, L. monocytogenes CECT 4032, and S. aureus CECT 976 has been investigated by Grande et al. (2005). Reduction of $B$. cereus LWL1 and L. monocytogenes CECT 4032 below the detection limit 10 CFU/ml) after 24 $\mathrm{h}$ of incubation was reported, whereas increased viable count of $S$. aureus CECT 976 was observed. But variable reduction of $S$. aureus CECT 976 from 2.0 to $2.8 \mathrm{log}$ units were detected up on prolonged incubation. Backialakshmi et al. (2015) also reported a considerable reduction of Listeria monocytogenes by antilisterial bacteriocin 101 and 102 produced by lactic acid bacteria as compared to chemical preservative, Sodium nitrate.

The antibacterial action of pediocin is stable in a wide range of $\mathrm{pH}$ (3-9) and processing temperature (61 $121^{\circ} \mathrm{C}$ ). It has wide spectrum of antibacterial activity on food borne pathogens and food spoilage bacteria. Pediocin has been applied in many foods as preservative, especially, animal origin. Reports indicate the possible usage of pediocin in fruit juices (Barbosa et al., 2017). It was demonstrated by Narsaiah et al. (2014) that a considerable microbial load reduction in minimally processed papaya by a coated pediocin after 21 days of storage, which confirm pediocin can be used to improve the shelf life of minimally processed papaya for three weeks with no significant change in physico chemical properties.

A review by Barbosa et al. (2017) summarized the potential of lactic acid bacteria derived bacteriocins in the preservation of fruit products. Bovicin HC5, produced by Streptococcus bovis HC5, has shown bacteriocidal 
potential against $B$. cereus, B. thuringiensis and C. tyrobutyricum and inhibited the outgrowth of endospores from Bacillus strains in acidic mango pulp. When applied in mango juice, it inactivated both vegetative cells and spores of $A$. acidoterrestris with the reduction of the D-values more than $90 \%$. In addition, Enterocin $416 \mathrm{~K} 1$ produced by Enterococcus casseliflavus IM 416K1 isolated from Italian sausages showed a strong antilisterial activity in apples and grapes, and found to be stable upon heating at $90{ }^{\circ} \mathrm{C}$ for $120 \mathrm{~min}$ and storage at $4{ }^{\circ} \mathrm{C}$ for 6 months making it a potential candidate for bio-preservation of fruit and vegetable products. Furthermore, bificin C6165 is another bacteriocin produced by strains of Bifidobacterium animalis subsp. animalis CICC 6165 perform well at acidic conditions and elevated temperature. Bificin C6165 exhibited antimicrobial activity against several strains of $A$. acidoterrestris, LAB strains and Gram-positive bacteria including $S$. aureus and Enterococcus faecium with a considerable reduction in thermal resistance of endospores. The review also strongly noted that the toxicological studies has to be done for safe use of the bacteriocin in preservation of fruit, vegetable and other food stuffs.

\subsubsection{Ready-to-Eat, Processed, and Canned Vegetable Foods}

A prolonged handling while preparing ready-to-eat vegetables by food handlers, exposure to abusive storage temperature and inadequate heat treatment before consumption are among the factors that enhance microbiological safety risks related to these food stuffs. For example, salad (Deli type salad) a very popular ready to eat vegetable foods containing a mosaic of cooked and uncooked vegetables: potatoes, tomatoes, olives, peas, carrots, lettuce or cabbage and ingredients like ham, chicken, tuna, egg, or seafood with mixture of mayonnaise or salad dressing. A low number of competent microbes in ready to eat vegetable foods pave the way for the proliferation and transmission of pathogenic microorganisms including $S$. enterica and $L$. monocytogenes, and are public health concern (Gálvez et al., 2014).

The application of enterocin AS-48 in Deli type salad alone had no profound effect on the viability of Salmonellae, when stored at $10^{\circ} \mathrm{C}$ for one week with $80 \mu \mathrm{g} / \mathrm{g}$ final concentration of the bacteriocin. In contrast, elegant performance of enterocin AS-48 was observed when it is used in combination with $0.5 \%$ PHBME. A significant decrease in viable count of salmonellae was achieved at higher concentration of bacteriocins $(80 \mu \mathrm{g} / \mathrm{g})$ by $3.0 \mathrm{log}$ of units within 3 hours of storage, and stayed below or slightly above the detection limit. Likewise, a remarkable reduction in viable count was observed when the bacteriocin is employed in combination with hydrocinnamic acid $(40 \mu \mathrm{g} / \mathrm{g})$ and 2-nitropropanol $(40$ and $80 \mu \mathrm{g} / \mathrm{g})$ at different concentration of bacteriocin (20$80 \mu \mathrm{g} / \mathrm{g}$ ); $2.3 \log$ units and $2.7 \log$ units during storage period, respectively (Molinos et al., 2009a). Antilisterial activity of enterocin AS-48 in Russian salad was investigated by Molinos et al. (2009b). The result indicated that antilisterial activity of enterosin AS-48 $(30 \mu \mathrm{g} / \mathrm{g})$ is markedly enhanced by essential oil, bioactive components of essential oils and plant extracts, natural antimicrobials, and food preservatives (organic compounds). $L$. monocytogenes was reduced by a treatment of salad with combination of enterocin as $-48(30 \mu \mathrm{g})$ and lactic acid, PHBME or Nisaplin for one week.

In processed vegetable foods, applying heat while cocking will kill vegetative cells, but is not high enough to kill or inactivate the endospores of some bacteria. To overcome the outgrowth of endospores, it is strongly recommended to use additional treatment like adding bacteriocins alone or in combination with other preservative. Research reports reveal the success in control of the growth of endospore using broad spectrum bacteriocins and/or preservatives. Grande et al. (2006) investigated the efficacy of enterocin AS-48 in inhibiting the germination of endospores in boiled rice and rice-gruel contaminated with both vegetative cells and endospores of Bacillus cereus. It was possible to reduce the viable count of vegetative cells below detection limit in storage period of 14 days at $6-37^{\circ} \mathrm{C}$ and at concentration of $20-30 \mu \mathrm{g} / \mathrm{ml}$. Moreover, the activity of enterocin AS-48 was increased by sodium lactate which depend on concentration used and avoid enterotoxin production. When enterocin AS-48 is applied in combination with heat, the heat sensitivity of endospore is remarkably increased. Therefore, applying enterocin AS-48 to food before heat treatment can kill endospores at low processing temperature that assures the consumers need for minimally processed and safe products at the same time reduce processing cost and time at the economic point of view. Similarly, Thomas et al. (2002) studied the potential of nisin in inhibiting the growth of spore former species of Bacillus and Clostridium. Incorporation of $6.25 \mu \mathrm{g} / \mathrm{g}$ nisin in cocked mashed potato hinders the growth of $B$. cereus and B. subtilis for at least 27 days at $8^{\circ} \mathrm{C}$. Furthermore, when the same product is treated with nisin in similar amount and vacuum packaged, the growth of C. sporogenes and Clostridium tyrobutricum growth was inhibited up to 58 days at $25^{\circ} \mathrm{C}$.

Schillinger et al. (2001) investigated the efficacy of nisin against Listeria monocytogenes alone and in combination of protective cultures. A minor reduction of viable count of L. monocytogenes was observed with regrowth when nisin is used alone, but a complete suppression of listerial growth was possible while adding nisin and bacteriocinogenic protective cultures of either Enterococcus faecium BFE 900-6 and Lactobacillus sakei BFE 902 in tofu stored at $10^{\circ} \mathrm{C}$ for one week.

Canning and cocking are among powerful mechanisms in combating vegetative cells of photogenic and spoiling microorganisms in processed vegetables. Nevertheless, endospores of some food important microbes can bypass these treatments as result of high thermal resistant capacity. Unless additional measure is taken as 
hurdle for these resistant forms such as refrigeration, acidification, addition of salt or chemical preservatives, it is too difficult to consume the products. Reports reveals the pivotal role played by bacteriocins to contest both vegetative cells and endospores of spore former microorganisms (Gálvez et al., 2014). The effect of the addition of enterocin EJ97 into low acid canned food to control the vegetative as well as endospore of Geobacillus strearothermophilus, responsible for the flat sour spoilage, was studied by Viedma et al. (2010). The result indicated that the viable count was reduced below the detection level after 30 days of storage at abusive temperature, $45^{\circ} \mathrm{C}$. Furthermore, the efficiency of enterocin EJ97 increases as temperature goes up at which endospore become bacteriocin sensitive. The findings of this study imply enterocin EJ97 is a potential candidate for the preservation of canned vegetable foods against Geobacillus strearothermophilus.

Enterocin AS- 48 exhibited a suppression effect against vegetative cells of Bacillus coagulans CECT in canned vegetative food products. The bacteriocin completely destroyed viable cells of Bacillus coagulans CECT after 15 days of storage at $4{ }^{\circ} \mathrm{C}, 22^{\circ} \mathrm{C}$ and $37^{\circ} \mathrm{C}$. The efficiency of enterocin AS- 48 is accelerated in the presence of acid, $1.5 \%$ lactic acid where it can kill and reduce viable count below the detection level within 24hour, and the addition of glucose and sucrose (10\% and 20\%) pronounced the effect of bacteriocin enterocin AS-48. Although a less significant impact on the endospore of Bacillus coagulans CECT was observed, thermal treatment can be increased by the sum total effect of enterocin AS- 48 and heat at $80-95^{\circ} \mathrm{C}$ for 5 minutes (Lucas et al., 2006). Enterocin AS-48 was tested against Geobacillus strearothermophilus in canned pea, corn and coconut. A reduced viable count below detection level was reported at concentration of $1.75 \mu \mathrm{g} / \mathrm{g}$ or $\mathrm{ml}$ after 30 days of incubation at $45^{\circ} \mathrm{C}$ and with regrowth during storage period. Activity against endospore was enhanced by addition of trypsin strengthens the bio-preservative efficacy of enterocin AS-48 (Viedma et all., 2009).

\subsection{Efficacy of bacteriocin in dairy product preservation}

Non- thermal treatments have got due attention by food industries as per a continuously growing consumer demand for minimally processed and microbiologically safe products. Among them, priority has been given to bacteriocins from lactic acid bacteria: nisin, pediocin PA-1, lacticin 3147, enterocin and could be important in dairy industry. Application of bacteriocin alone or in combination with other methods are hopeful scenario for improved microbiological safety and sustainable organoleptic property of dairy products (Sobrino-Lopez and Martin-Belloso, 2008).

Lactic acid bacteria and their bacteriocins are profoundly studied for their efficiency in preservation of dairy products. One of the bacteriocin intensively researched is nisin for preservation of dairy products. Oshima et al. (2014) evaluated the potential of nisi A in controlling the growth of spore forming bacteria: Bacillus and Paenibacillus in chilled high-fat milk pudding to reduce heat treatment to improve aroma and flavor while extending the shelf life. In this study, the addition of nisin A at $80 \mathrm{IU} / \mathrm{g}$ and upper concentrations in $5.0 \%$ fat milk pudding inoculated with $B$. thuringiensis increased the shelf life to 20 days at inappropriate storage temperature of $15-20^{\circ} \mathrm{C}$, whereas the same amount of nisin A has bacteriostatic effect on Bacillus cereus in milk of $5 \%$ fat content keeping the number of the pathogen below detection level ( $\left.10^{7} \mathrm{CFU} / \mathrm{g}\right)$ for 29 days at 20 and $30^{\circ} \mathrm{C}$. Nisin A prevented the growth of Paenibacillus jamilae at concentration of more than $40 \mathrm{IU} / \mathrm{g}$. After pasteurization at $130^{\circ} \mathrm{C}$ for 2 seconds, the residual activity levels observed indicated high retention with only $25-50 \%$ loss in nisin A activity for up to 27 days at $15^{\circ} \mathrm{C}$ and neutral $\mathrm{pH}$. The study also showed a decrease in nisin A activity along with the increase in fat content of the dairy products. The efficacy of nisin in combination with bovicin HC5 against Listeria monocytogenes and Staphylococcus aureus in fresh cheese was determined by Pimentel-Filho et al. (2014). The study indicated the combination of nisin and bovicin HC5 at concentration of $600 \mathrm{AU} / \mathrm{g}$ is effective in the control of L. monocytogenes growth after 30 days of storage at $4^{\circ} \mathrm{C}$. Although the growth of Staphylococcus aureus was retarded by the combined effect of the bacteriocins, production of enterotoxin was detected. Arques et al. (2011) reported a complete in activation of Staphylococcus aureus and Listeria monocytogenes at refrigeration temperatures. The treatment of Greek soft acid-curd cheeses with nisin increased the shelf life up to 21 days at $4{ }^{\circ} \mathrm{C}$ by maintaining good sensory characteristics (Kykkidou et al., 2007).

Pediocin is another bacteriocin applied in dairy products to enhance shelf life and product safety. Pediocin is mostly added to meat products; however, it has been tested in many dairy products: dressed cottage cheese, half-and-half cream, and cheese sauce to inhibit the growth of Listeria monocytogenes. Pediocin 5 from P. acidilactici UL5 has shown bactericidal effect against L. monocytogenes in milk (G'alvez et al., 2008). A significant inhibition of Staphylococcus aureus, total viable count and lactic acid bacterial count was observed in preservation of buffalo milk by Pediocin PA-1 Containing Fermented Cheese Whey level of $2.04 \times 10^{5}$ AU/ml (Verma et al., 2017). Reports show the potential of pediocins are much more effective than nisin against food borne pathogens such as L. monocytogenes and $S$. aureus and gram-negative bacteria including Pseudomonas and Escherichia coli (Silva et al., 2018).

Lacticin produced by Lactococcus lactic consisting of lacticin 3147 and lacticin 481 confer a considerable reduction of pathogenic and spoiling microbes in dairy products (Silva et al., 2018). The demonstration by Martinez- cuesta et al. (2010) in controlling late blowing cheese with the addition of Lacticin 3147 producing 
strain Lactocuccus lactis IFPL 3593 that has exhibited inhibition of Clostridia spore germination in preventing late blowing in semi hard cheese, with a reduction of spore by $5 \mathrm{log} / \mathrm{g}$. The strain also revealed a capacity in hampering the growth of heterofermentative lactobacilli having blowing effect on the product. Correspondingly, a powdered preparation of lacticin 3147 was found to be effective for the control of Listeria and Bacillus in natural yogurt, cottage cheese and soup as well as products containing dairy ingredient (Morgan et al., 2001). Unlike Lacticin 3147, lacticin 481 has a narrow spectrum usually to lactic acid bacteria, Clostridium tyrobutyricum and L. monocytogenes. A cell free supernatant containing lacticin 481 has shown a bacteriostatic at refrigeration temperature, while a semi purified reduced L. monocytogenes by 3 log cycles in 3-7 days (Silva et al., 2018).

Enterocins are the most widely applied group of bacteriocin to combat food borne pathogens and spoilage microbes in food. One of which is enterocin AS-48 thoroughly studied for food application. Munoz et al. (2007) conducted a research on the efficacy of enterocin AS-48 in hindering the growth of Staphylococcus aureus in skim milk and fresh cheese. The bacteriocidal effect of enteerocin AS-48 was done in skim milk at different concentration. Although viable count of $S$. aureus was less than the control, complete elimination was not achieved; all the treated samples recover after 2 hours of incubation. This indicate that enterocin is not effective in skim milk. Nevertheless, sub-lethal heat treatment significantly reduced the viable count as concentration increases, especially, at concentration of $20 \mu \mathrm{l} / \mathrm{ml}$ or above a decrease below detection level after 6 hours of incubation was observed. This implies enterocin AS-48 is potentiated by heat treatment to eliminate the pathogen.

Listeria monocytogenes inhibitory potential of enterocin AS -48 was examined in a fresh cheese, which provides Listeria monocytogenes with optimum growth conditions, model by Ribeiro et al. (2017). A semi purified enterocin AS-48 reduced Listeria monocytogenes growth depending on the concentration used. The lower concentration was $134 \mu \mathrm{g} / \mathrm{ml}(512 \mathrm{AU} / \mathrm{ml})$ resulted in 10 -fold decrease in listeria count after 72 hours of incubation at $4{ }^{\circ} \mathrm{C}$, but the dose was not enough to hinder pathogen growth. Fortunately, the viability of Listeria monocytogenes was reduced below the detection limit when the extract is applied at concentration of $536 \mathrm{lg}$ (2,048 AU) per gram of cheese and remain undetected after incubation period. Similarly, another type of enterocin, enterocin KP reduced listerial viable count below the detection limit throughout storage period in skim milk sample with less fat content and low efficacy was seen in milk sample containing high fat content. This attributes to the ability of enterocin to penetrate the fat to reach the target cell; low hydrophobicity nature (Yildrim et al., 2016).

Enterocin CCM 4231 has similarly been tested for pathogenic and spoiling microbes in dairy products. In skimmed milk sample a marked decrease was observed in Staphylococcus aureus 1 from $10^{10} \mathrm{cfu} / \mathrm{ml}$ to $10^{2}$ $\mathrm{cfu} / \mathrm{ml}$ after 24 hours incubation and significant inhibition of the same strain in yogurt preparation was noticed from $10^{6} \mathrm{cfu} / \mathrm{ml}$ to $10^{3} \mathrm{cfu} / \mathrm{ml}$ after 3.5 hours incubation. In addition, during yogurt preparation enterocin CCM 4231 reduced viable cells of Listeria monocytogenes from $10^{4} \mathrm{cfu} / \mathrm{g}$ to $10^{2} \mathrm{cfu} / \mathrm{ml}$. Furthermore, an elegant reduction viable count of Listeria innocua from $10^{6} \mathrm{cfu} / \mathrm{gmlto} 10^{3} \mathrm{cfu} / \mathrm{ml}$ after one-week storage at $4^{\circ} \mathrm{C}$ with the addition of $6400 \mathrm{AU} / \mathrm{ml}$ enterocin CCM 4231. Moreover, complete removal of enterococci and staphylococci, and reduction of $E$. coli $10^{3} \mathrm{cfu} / \mathrm{ml}$ to $10^{2} \mathrm{cfu} / \mathrm{ml}$ was reported (Khan et al., 2010).

\section{Efficacy of plant derived metabolites}

The demand for natural preservatives has recently given considerable attention, since consumers become conscious about the negative health impact of synthetic food preservatives. One of the different sources of natural preservative is plant derived antimicrobial compounds from edible, medicinal, herbal plants, and their derived essential oils (EO) and compounds from residual of purification procedure contain a large array of secondary metabolites with astonishing inhibitory effect on the growth of bacteria, yeast and molds of food industry importance. Most of them are not fully elucidated and commercialized. The antimicrobial compounds of plant material are found in essential oils extracted from leaves, (rosemary, sage, basil, oregano, thyme, and marjoram), flowers or buds (clove), bulbs (garlic and onion), seeds (caraway, fennel, nutgem, and parsley), rhizomes (asafetida), fruits (pepper and cardamom), or other parts of plants (Tiwari et al., 2009).

Even though limited research on structure- function relation on antimicrobial efficiency of plant derived compounds are available, it is supposed that the antimicrobial efficacy of plant extract depends largely on the presence of phenolic compounds or other hydrophobic components in the essential oils. Plant by products from fruit and vegetables (seeds, peels, pulps, unused flesh, and husks) are also mentioned as potential source of antimicrobial compounds (Gyawali and Ibrahim, 2014).

The application of plant EOs for controlling the growth of foodborne pathogens and food spoilage microbes requires evaluation of the range of activity against the organisms of concern to a particular product, as well as effects on organoleptic properties of food (Tiwari et al., 2009).

3.1. Plant derived compounds/ essential oils

The antimicrobials from plant refers to the antioxidant or antimicrobial activity of herbs, spices, and their 
compounds (Gyawali and Ibrahim, 2014). Traditionally, herbs and spices are used as medicine, flavoring agents and for food preservation. Moreover, Spices have been regarded as permanent ingredient in household culinary practices. For this reason, they are adopted as a part of daily diets worldwide. Spices: Clove, garlic, cinnamon, rosemary, cumin, oregano, bay, thyme, mustard, basil, pepper, ginger and sage, have been proven for their antimicrobial potential against pathogenic and spoilage microbes: Staphylococcus spp., Escherichia spp., Listeria spp., Pseudomonas spp., Aspergillus spp., Cladosporium spp. and Salmonella spp. The antimicrobial activity relay on a number of factors: Type of microorganism, nature of food product, type of spices essential oils and extracts (Saeed et al., 2016).

The chief group of compounds with antimicrobial activities from plants are phenolics, phenolic acids, quinones, saponins, flavonoids, tannins, coumarins, terpenoids and alkaloids. The antimicrobial activity differs according to the structural and chemical constitution of these compounds. The presence and the position of - $\mathrm{OH}$ group is the core of the immense role of antimicrobial action: make them to react with the bacterial cell membrane causing leakage of important cellular components, promotes delocalization of electron acting as proton exchanger and reduce proton motive forces across the cell membrane and ATP pool thereby, make microbes to loose life integrity and ultimately kill the undesired microbes in food system. In addition, free $-\mathrm{OH}$ functional group binds with the active sites of enzymes and create metabolic imbalance, and reduces the reactive oxygen species in growth medium that deteriorate the redox potential of the growth medium (Gyawali and Ibrahim, 2014). In situ and ex situ evaluation of essential oils reveals the possible scenario of application for natural food preservation.

Several investigations have been done on the efficiency of plant derived compounds in tackling food abusing microbes in selected food system; in situ investigation. Zhang et al. (2009) studied the antimicrobial activity of 14 spice extracts against four common meat spoilage and pathogenic bacteria (Listeria monocytogenes, Escherichia coli, Pseudomonas fluorescens and Lactobacillus sake). The results showed that individual extracts of clove, rosemary, cassia bark and liquor ice contained strong antimicrobial activity, but the mixture of rosemary and liquor rice extracts was the best inhibitor against all four types of microbes; showed a considerable reduction of the potent microbes during 28 days of storage at $4^{\circ} \mathrm{C}$. Similarly, the sensory evaluation study of refrigerated fish showed that the shelf life of fish patties was 8,10, and 14 days for the groups treated with thyme, clove and rosemary essential oil, respectively, while 4 days for the control (Guran et al., 2015). Recently, Dimitrijevi et al. (2018) investigated the effects of carvacrol and eugenol, separately and in combination, on the survival of Listeria monocytogenes, and sensory and microbiological characteristics in vacuum packaged Oncorhynchus mykiss during refrigerated storage $\left(4 \pm 1{ }^{\circ} \mathrm{C}\right)$ for 20 days. A significant reduction on the population of Listeria monocytogenes by $1.35-2.84 \mathrm{log} \mathrm{cfu} / \mathrm{g}$, compared to the control fillets was observed. Sensory analysis showed that fish fillets with eugenol added were the most acceptable to trained panelists. The evaluation of antimicrobial potency of EOs from lemon balm, marjoram, oregano and thyme against Enterobacter spp., Listeria spp., Lactobacillus spp., and Pseudomonas spp. using food model of lettuce, meat and milk showed a Listeria spp. were more sensitive than spoilage bacteria while oregano and thyme were the most active Eos. The result also depicts that EOs are more effective against food-borne pathogens and spoilage bacteria when applied to foods containing a high protein level at acidic $\mathrm{pH}$, as well as moderate levels of simple sugars (Gutierrez et al., 2009). Faïza et al. (2018) assessed the performance of application of Artemisia herba-alba aqueous extract in traditional fresh cheese preservation. The result has shown a marked decrease in the mesophilic aerobic, coliform and lactobacilli count, while yeast and molds count showed a slowest significant increase during 15 days of storage at $4{ }^{\circ} \mathrm{C}$, because the raw milk used is not heat treated for cheese preparation. Hence, heat treatment is strongly recommended by the authors for effective preservation by the plant extract.

A number of researchers from all over the world has assessed the antimicrobial efficacy of plant derived compounds and essential oils of spices and herbs ex situ. Friedman eta al. (2002) evaluated the bactericidal activity levels of 96 essential oils and 23 oil compounds against Campylobacter jejuni, Escherichia coli O157:H7, Listeria monocytogenes, and Salmonella enterica obtained from food and clinical sources. It was obtained that all strains exhibited similar susceptibilities to inactivation by both essential oils and oil compounds with bactericidal activity (the percentage of the sample in the assay mixture that resulted in a $50 \%$ decrease in CFU relative to a buffer control) within the range of 0.003 to 0.092: C. jejuni (with BA50 values ranging from 0.003 to 0.009 ) inactivated by oils of marigold, ginger root, jasmine, patchouli, gardenia, cedarwood, carrot seed, celery seed, mugwort, spikenard, and orange bitter oils; those that were most active against E. coli (with BA50 values ranging from 0.046 to 0.14 ) were oregano, thyme, cinnamon, palmarosa, bay leaf, clove bud, lemongrass, and all spice oils; those that were most active against L. monocytogenes (with BA50 values ranging from 0.057to0.092) were gardenia, cedarwood, bayleaf, clovebud, oregano, cinnamon, allspice, thyme, and patchouli oils; and those that were most active against $S$. enterica (with BA50 values ranging from 0.045 to 0.14 )were thyme, oregano, cinnamon, clove bud, all spice, bay leaf, palmarosa, and marjoram oils. However, the susceptibility of Campylobacter jejuni to the bactericidal influence of similar natural compounds was much 
greater than the rest of the strains.

Mostafa et al. (2018) has studied the bacteriostatic and bacteriocidal efficiency of plant extracts against Bacillus cereus, Staphylococcus aureus, Escherichia coli, Pseudomonas aeruginosa and Salmonella typhi. Ethanolic extracts of Punica granatum, Syzygium aromaticum, Zingiber officinales and Thymus vulgaris variably inhibited the tested pathogens at concentration of $10 \mathrm{mg} / \mathrm{ml}$, whereas Cuminum cyminum was effective against Staphylococcus aureus. Extraordinary bacteriostatic and bacteriocidal activity against Staphylococcus aureus and Pseudomonas aeruginosa with MIC range of 2.5 to $5 \mathrm{mg} / \mathrm{ml}$ and MBC of 5 and $10 \mathrm{mg} / \mathrm{ml}$, respectively was obtained. The authors have proven the extracts can be used to control spoiling and pathogenic microbes in food stuffs with possible enhancement of shelf life.

Gram negative and gram-positive bacteria and yeast species were tested for the bacteriocidal potency of essential oils from Rosa alba by Gochev et al. (2010). The gram-positive bacteria (Staphylococcus and Bacillus), gram negative (Escherichia, Pseudomonas, Salmonella and Citrobacter) and yeast (Candida) were investigated for resistance to essential oils and pure compounds. As it is illustrated by the result gram negative bacteria, especially, Pseudomonas spp. are more resistant than gram positive to both essential oils and pure components; attributes to the complex cell wall structure- a complex hurdle for essential oil penetration.

Škrinjar and Nemet (2009) has reviewed antimicrobial activity of essential oils from widely used spices and herbs, such as garlic, mustard, cinnamon, cumin, clove, bay, thyme, basil, oregano, pepper, ginger, sage, rosemary against most common bacteria and fungi that contaminate food (Listeria spp., Staphylococcus spp., Salmonella spp., Escherichia spp., Pseudomonas spp., Aspergillus spp., Cladosporium spp. and many others). According to the review the relative efficacy of antimicrobial activity of essential oils can be evaluated irrespective of the factors that determine the efficiency: the type of spice or herb, type of food and microorganism, the chemical composition and content of extracts and essential oils, cinnamon, cloves and mustrad have very strong antimicrobial; potential, cumin, oregano, sage, thyme and rosemary show medium inhibitory effect, and spices such as pepper and ginger have weak inhibitory effect.

\section{Efficacy of animal derived metabolites}

A number of antimicrobial metabolites from animals have already been described and documented, which primarily are evolved as host defense mechanisms. Many of the antimicrobial agents inherent to animals are in the form of antimicrobial peptides (polypeptides). Isolation of antimicrobial peptides dated back to 1950, when nisin was obtained from lactic acid bacteria for the purpose of food preservation. Since then, AMPs are isolated from various sources including: plants, insects, amphibians, crustaceans, and marine organisms. Besides, AMPs are the prime promising option for the existing antibiotic resistant challenges, due to the distinct behaviors: specific molecular sites are not targeted, and their characteristic rapid destruction of membranes does not allow sufficient time for even fast-growing bacteria to mutate: develop mechanism of resistance by altering genetic makeup (Tiwari et al., 2009). Few of the animal origin AMPs are discussed with respect to application in food preservation.

\subsection{Lactoferrin}

Lactoferrin is an iron-binding glycoprotein $80 \mathrm{KDa}$ antimicrobial found in milk and other exocrine sections as innate immune system. In addition to fundamental biological function, binding and transport of iron ions, lactoferrin has considerable antimicrobial action against viruses, parasites and bacteria; and play anticancer and antiallergic role. The primary antimicrobial mechanism is sequestering free iron, and thus remove essential substrate required for bacterial growth (Duran and Kahve, 2017). Lactoferrin is approved to be used in food preservation system by some countries including USA, where it is legally accepted to be applied in beef and other products (Gyawali and Ibrahim, 2014). Besides, many research reports on the antimicrobial effect of lactoferrin confirmed that LF is a promising additive to enhance the quality and safety of food stuffs.

Shashikumar and Puranik (2011) conducted research on the bio-preservation of paneer by lactoferrin. They reported that reduction in bacterial growth is proportional to the lactoferrin level, where increase in lactoferrin level significantly decrease bacterial growth as compared to the control, thereby considerably extend the shelf life. The shelf life of paneer was extended up to 7 days at room temperature $\left(30^{\circ} \mathrm{C}\right)$ and 15 days at refrigerated temperature $\left(4^{\circ} \mathrm{C}\right)$ when treated with $20 \mathrm{ppm}$ lactoferrin, while the control with a shelf life of 2 days at $30^{\circ} \mathrm{C}$ and 7 days at $4{ }^{\circ} \mathrm{C}$, respectively. Likewise, Colak et al. (2008) demonstrated the effect of lactoferrin and its combination with nisin on the microbial load of meatball stored at refrigeration temperature. The treatment of meatball with lactoferrin only reduced the total aerobic bacteria, coliform, E. coli, total psychrophilic bacteria, Pseudomonas spp., and yeast and mold count significantly. However, a pronounced reduction was seen in meatball treated with a mixture of $\mathrm{Lf}(200 \mathrm{mg} / \mathrm{g})$ and nisin $(100 \mathrm{mg} / \mathrm{g})$, which increase the refrigeration shelf life of naturally contaminated meatballs to 10 days compared to 3 days for nontreated control.

Invitro antimicrobial efficacy of lactoferrin has been reported by a number of researchers against common food borne pathogens and spoilage microorganisms. Murdock et al. (2006) has shown that an effective 
inhibition of Listeria monocytogenes at $1000 \mu \mathrm{g} / \mathrm{ml}$ lactoferrin, whereas initially inhibited the growth of $E$. coli O157:H7, although regrowth was observed. when applied at $500 \mu \mathrm{g} / \mathrm{ml}$ with nisin at $250 \mathrm{IU} / \mathrm{ml}$ considerably inhibited the growth of $E$. coli $\mathrm{O} 157: \mathrm{H} 7$, while $250 \mu \mathrm{g} / \mathrm{ml}$ of lactoferrin and $10 \mathrm{IU} / \mathrm{ml}$ of nisin were inhibitory to L. monocytogenes; best work in synergy with nisin. A similar study by Brown et al. (2008) chitosan film coated lactoferrin against same pathogens indicated a lower inhibitory efficacy when it was used alone. Nevertheless, the efficacy of lactoferrin was maximized by combined application with lysozyme-containing chitosan film.

The antimicrobial activity accounts for some basic properties of lactoferrin: create nutrient deficiency through iron chelation results in iron deficiency in the growth medium, destabilization of outer membrane of gram-negative bacteria by releasing lipopolysaccharide that brings about membrane permeability. This intern increases antimicrobial effect of commercialized drugs like rifampicin. It was also explained that lactoferrin and Bifidobacterium spp. work together against pathogenic microbes through two mechanisms: (1) lactoferrin provide Bifidobacterium spp. with iron which is a growth promotor while depriving the pathogens from iron for growth, and (2) under low iron conditions Bifidobacterium spp. produce bifidogenic compounds that greatly inhibit the growth of pathogens. Thus, the application of medium with lactoferrin and Bifidobacterium strains may be helpful in assuring microbiological safety and stability (Gyawali and Ibrahim, 2014).

\subsection{Lysozyme}

Lysozyme is a natural component of avian egg and mammalian milk with antimicrobial and graded generally regarded as safe (GRAS) which has been applied in pharmaceutical and food industries. The enzyme is used as preservative in meat and meat products, fish and fish products, dairy products, fruit and vegetables (CegielskaRadziejewska et al., 2009). The ability of lysozyme to break $\beta-1,4$ linkage between $\mathrm{N}$-acetylmuramic acid and $\mathrm{N}$-acetylglucosamine in the peptidoglycan of the microbial cell wall contribute in maintaining the microbial safety and quality of food (Bilej, 2015).

The antimicrobial activity of lysozyme against both gram negative and gram-positive bacteria was evaluated by researchers. Abdou et al. (2007) investigated the inhibitory efficacy of lysozyme peptide preparation, which showed only $11 \%$ of lysozyme enzyme activity. Complete inhibition of B. subtilis, $B$. licheniformis, B. megaterium, B. mycoides, B. pumilus, B. coagulans, B. amyloliquefacienes, B. polymexa and B. macerans at $100 \mu 1 / \mathrm{mg}$ was reported, whereas $B$. cereus and $B$. stearothermophilus have showed resistance. The most important features of the preservative (lysozyme peptide) as a promising preservative candidate against spoilage Bacillus species are: capable of inhibiting both vegetative and spore forms when applied $\geq 10 \mu \mathrm{g}$ and stable at temperature as high as $95^{\circ} \mathrm{C}$ and $\mathrm{pH}$ between $4.5-7$. Thermochemical modification of lysozyme antimicrobial activity was studied by Cegielska-Radziejewska et al. (2009). The authors reported that thermochemically modified lysozyme showed bacteriostatic effect on both gram negative and gram-positive bacteria. It was possible to effectively inhibit Pseudomonas mirabilis, Pseudomonas fluorescence and Escherichia coli using lysozyme preparation with high dimmer content. A monomer lysozyme preparation has also exhibited considerable reduction in the count of Staphylococcus epidermidis and Escherichia coli. Both chemical and thermal treatment results in the formation of oligoforms which increase antimicrobial activity spectrum. Heat and chemical denatured hen egg white lysozyme sufficiently inhibited gram-negative bacteria Escherichia coli ATCC 25922and gram-positive bacterium Staphylococcus carnosus CECT4491T (Vilcacundo et al., 2018).

Lysozyme has been applied in different foods as preservative to improve the microbial safety and stability. It was primarily used to protect late blowing defect in cheese due to the growth of Clostrodium tyrobutyricum. Lysozyme has also shown antimicrobial activity against Listeria innocua and Saccharomyces cerevisiae with an inhibition zone of 19.75 and $17.37 \mathrm{~mm}$, respectively (Nazir et al., 2017). Furthermore, sufficient preservation of alcoholic beverage by lysozyme including beer at $\mathrm{pH} 4.7$, reduction of Listeria monocytogenes in raw minced tuna and salmon roe products, and raw and processed meat and milk products was indicated in many research reports (Juneja et al., 2012).

\subsection{Chitosan}

Chitosan is a natural biopolymer found in exoskeleton of crustaceans and arthropods, and is an effective antibacterial and antifungal agent of food industry interest as potential preservative (Tiwari et al., 2009). The wide antimicrobial activity and low toxicity against mammalian cells make chitosan among suitable natural preservative applied in variety of food stuffs (Juneja et al., 2012). The efficacy of chitosan was further strengthened by investigation of various scientists. Fernandes et al. (2008) has shown the bactericidal activity of chitosan and chitooligosaccharides against Staphylococcus aureus and Escherichia coli depending on the inoculum level and concentration applied in model food system. In liquid food matrices, incorporation of medium and high molecular weight chitosan maintains their activity, both in matrices and bacteria, but lower in milk, whereas they lost activity in milk after 4 to 8 hours. In contrast, application of chitosan and 
chitooligosacharide in apple juice brings about offensive flavor and taste. In addition, Je and Kim (2006) demonstrated the mechanism of antimicrobial action of chitosan and derivatives to be outer and inner membrane disruption.

Application of chitosan to food improve the shelf life up to considerable days. Addition of $0.05 \mathrm{~g}$ per $100 \mathrm{ml}$ acetic acid in noodle extend for 6 day at $4^{\circ} \mathrm{C}$. Two months of shelf life was observed in treatment of pasta with chitosan and modified atmosphere packaging at $4^{\circ} \mathrm{C}$. Chitosan- lysozyme-based coatings can enhance microbial safety and extend shelf life of hard-boiled eggs by controlling postprocessing contamination and delaying undesirable changes in egg quality. In cheese, chitosan-based edible coating and combination of chitosan coating and modified atmosphere packaging significantly extend the shelf life, and maintain quality of the product. Similar reports on shelf life and quality stability improvement have indicated chitosan and derivatives as potential candidate for bio-preservation of products for considerable period of time (Friedman and Juneja, 2010).

\subsection{Other AMPs from animals}

Different antimicrobial agents are well studied and reported as effective food preservative. Among which animal origin are discussed above, in addition many antimicrobials from animals are also found to be capable of defending food borne pathogens and spoilage microbes including Pleurocidin, Protamine, Defensins and Lipidins (Juneja et al., 2012).

Pleurocidin is present in myeloid cells and mucosal tissues of many vertebrates and invertebrates, and provides a natural defense system that reduces the mortality of fish infected with pathogenic microorganisms (Juneja et al., 2012). Besides, it exhibited antimicrobial impact on potent food borne pathogens such as $L$. monocytogenes and E. coli O157:H7, Saccharomyces cerevisiae, Penicillium expansum, Vibrio parahemolyticus and pathogenic fungi. The antimicrobial activity of pleurocidin is reported to be below the acceptable limits of nisin with no significant impact on host cells like red blood cells. This show Pleurocidin to be highly effective natural preservatives in food stuffs with low calcium and magnesium ions which negatively affect antimicrobial activity (Tiwari et al., 2009).

Protamine is a natural cationic antimicrobial peptide obtained from salmon and has broad broad antimicrobial activity against gram-positive bacteria, gram-negative bacteria, and fungi. The modified form, low charge, has shown more efficient inhibition than natural protamine against the growth of L. monocytogenes in milk as well as total bacteria and coliforms in ground beef. Thus, protamine with reduced charge is much more effective than the native form in food matrices containing high protein (Potter et al., 2005).

Defensins are group of antimicrobial peptides naturally found in many animals and have broad-spectrum antimicrobial activities against fungi, viruses, and gram-positive and gram-negative bacteria. They are found in cells and tissues of animals as host defines to get the control of foreign microbes (Tiwari et al., 2009). The wide spectrum of antimicrobial action defensins is due to permeabilization of cell membrane followed by inhibition of RNA, DNA and protein synthesis (Ganz, 2003).

Lipids of animal origin, from mucosal surfaces and milk, are proven to inhibit a vast array of microorganisms. Free fatty acids of mucosal surfaces have shown inactivation of S. aureus that of milk derived lipids substantially inactivate gram positive bacteria: $S$. aureus, Cl. botulinum, B. subtilis, B.cereus, L.monocytogenes, Gram-negative bacteria such as P.aeruginosa, E.coli, and Salmonella enteriditis and also against various fungi such as Aspergillus niger, Saccharmyces cerevisiae, and C. albicans. In addition, lipids can render multiplication and prevent the incorporation of pathogenic and spoilage microbes in food matrices (Shim et al., 2007). Eight carbon fatty acids from breast milk and bovine milk exhibited inactivation of Enterobacter sakazakii in infant formula. Biologically transformed extracts of eicosapentaenoic acid (EPA) and docosahexaenoicacid (DHA), obtained from fish and shell fish, are fount to have broad antimicrobial spectrum: gram-positive and gram-negative bacteria, including S. enteritidis, Salmonella Typhimurium, E. coli O157:H7, L. monocytogenes, and S. aureus (Juneja et al., 2012).

\section{Bio-preservation in hurdle technology}

Hurdle technology is an emergent technique in food technology for the preservation of food of different origin. Hurdle technology is the application of combinations of preservatives to maintain the quality and stability of the product, while enhancing nutritional and sensory qualities. The factors employed in food preservation are called hurdles, which comprises of heat, refrigeration, preservatives and irradiation applied in combination to render the growth of or to avoid microorganisms responsible for food spoilage and poisoning. The system, hurdle technology, consists of at least two hurdles to create adverse conditions for the microorganism/s to get the control of food important microbes towards increasing the shelf life of products. The effectiveness of hurdle technology relies on finding the appropriate combination of hurdles for optimum preservation, thereby it can ensure the safety, stability, organoleptic and nutritive quality of food for quite a long time. While choosing mildintensity measures as a factor in the hurdle system, one must consider a concept of microbial homeostasis, which is microbes physiological mechanisms to overcome any change in the external environment to keep stable and 
uniform intracellular condition, including: cell membrane structure, DNA replication, enzymatic activities, protein synthesis, $\mathrm{pH}$ regulation and redox potential (Eh) as hurdle target. Thus, hurdle technology is supposed to be an excellent scenario in food industries with multi targeted preservation approach in food industries (Renye et al., 2015, Pal et al., 2017 and Singh et al., 2014).

The increasing public health concern related to repeated exposure and consumption of artificial preservatives forced researchers and food industries to look for substituents either to reduce or eliminate the use of synthetic preservatives. Hence, hurdle technologies should include natural preservatives as a major hurdle to meet the growing public demand and mitigate heath concern. This part will review the involvement of biopreservatives in hurdle technology application to preserve common food stuffs.

In hurdle technology live organisms and their products are used as major component of hurdle system. Microorganisms or their metabolites are combined with other natural or artificial chemicals and physical treatments under sublethal levels. A successful hurdle technology has been done for the preservation of salamitype fermented sausages, which is kept fresh for extended periods at ambient temperature. The hurdle starts with the suppression of indigenous microorganisms with salt and nitrite treatment, followed by redox potential reduction by the growth of survivals of the first hurdle. At this low redox potential lactic acid fermenting bacterial growth is promoted, that lower the $\mathrm{pH}$ to prevent contamination. The water activity is declined through further aging process, since the sausage is dried out upon extended storage as a main hurdle (Renye et al., 2015).

Several reports have shown the immense role of bio-preservatives in hurdle technology to preserve various products for considerable periods of time. Turgis et al. (2012) has illustrated the synergy of nisin and $\gamma$-radiation to hamper the proliferation of Listeria monocytogenes and prolong the shelf life of meat up to 5 days of storage at $4^{\circ} \mathrm{C}$. Similarly, Huq et al. (2015) demonstrated the combined effect of microencapsulated formulation of nisin $(16 \mu \mathrm{g} / \mathrm{ml}$ and essential oils of oregano (Origanum compactum, $250 \mu \mathrm{g} / \mathrm{ml}$ ) and cinnamon (Cinnamomum cassia, $250 \mu \mathrm{g} / \mathrm{ml}$ ), and $\gamma$-radiation to inhibit Listeria monocytogenes on ready-to eat (RTE) ham during storage. The synergy of microencapsulated nisin and essential oils combined with $\gamma$-radiation more pronounced than the nonencapsulated formulation. The findings of the authors indicated that strong synergistic effect of encapsulated nisin and essential oils, and $\gamma$-radiation up to 28 days of chilled storage, which keep bacterial counts below the detection limit $(\leq 50 \mathrm{CFu} / \mathrm{g})$. The advancement of microencapsulation technology is, therefore, supposed to be a promising hurdle system for efficient means of food safety improvement in RTE meat market.

Scientific research reports have also confirmed the efficacy of bio-preservatives as a major factor in hurdle technology, especially in preservation of fruit and vegetable origin food. The study of Viedma et al. (2009) on the efficacy of enterocine AS-48 in suppressing exopolysaccharide producing strain Lactobacillus diolivorans 29 in combination with high - intensity pulsed- electric field in (HIPEF) in apple juice forms strong hurdle against the spoilage strain. The result revealed that microbial inactivation increases with the increase in the concentration of bacteriocin and electric field. Maximum inhibition was achieved by $1000 \mu$ s HIPEF combined with $2.0 \mu \mathrm{g} / \mathrm{ml}$ enterocin AS-48, whereas treatment of the product with individual factors didn't prevent the growth of the survivors during storage. The combined treatments completely inactivate survivors within $24 \mathrm{~h}$ and the product remain free from detectable lactobacilli after 15 days of storage at $4{ }^{\circ} \mathrm{C}$ and $22^{\circ} \mathrm{C}$. Viedma et al. (2010) has also worked on the bacteriocidal effect of combination of polyethene film coated with enterocin EJ97 and EDTA. The highest activity was observed when the sample inoculated with Bcillus coagulans CET 12 is stored at $4{ }^{\circ} \mathrm{C}$. The maximum performance of EDTA and bacteriocin alone was seen at $20^{\circ} \mathrm{C}$ and $4{ }^{\circ} \mathrm{C}$, respectively, which attributes to the high solubility of EDTA at $20^{\circ} \mathrm{C}$. Viable cell count gradually decreased throughout incubation period controlling the growth of bacilli. Moreover, Molinos et al. (2009) investigated the enhancement of enterocin AS-48 by combining with licensed preservatives; essential oils and bioactive extracts of plant. The antimicrobial activity against Listeria monocytogenes is more pronounced when enterocin AS-48 is applied together with other preservatives than separately used in Russian salad preservation for 10 days at $10^{\circ} \mathrm{C}$. Bioactive compounds of essential oils have a dual purpose together with enterocin AS-48 in salad; serve as antioxidant to protect salad from oxidation and product safety towards increasing the shelf life. Addition of chemical preservatives and enterocin AS-48 results in complete inactivation of Listeria monocytogenes below detection limit during one-week storage. Therefore, combination of bacteriocins, essential oils, bioactive extracts of plant and approved chemical preservatives form a strong hurdle system to control the regrowth of survivors than single bioactive application.

The combined application of bacteriocins with non-thermal treatments, organic acids and different packaging materials has been reported in many scientific articles as presented in the review by Deegan et al. (2006). Although the non-thermal treatment, HHP and pulsed electric filed are effective in combating spoilage and pathogenic microbes in food without severe damage to the nutritional composition as compared to thermal process, they are not feasible in economic point of view. But together with natural preservatives like bacteriocins (lacticin 3147, nisin) and bacteriocin producing strains, synergistically affect many food important microbes: Staphylococcus aureus, L. innocua, and E. coli 0157:H7 in products such as cheese at different ranges of pressure. Similarly, bacteriocins (pediocin and nisin) have been studied for antimicrobial efficacy in concert 
with organic acids and vacuum packaging. Strong synergy was observed in controlling Listeria monocytogenes, Clostridium perfringens and Salmonella enterica after some period of storage, where bacteriocin efficacy was enhanced by the addition of organic acids: sodium acetate, sodium diacetate and phytic acid. Furthermore, bioactive packaging was potentiated with immobilization of bacteriocins to the food packaging or the incorporation of pouch containing bacteriocin that gradually defuse to the food during storage. Bio-active packaging is reported to be effective with vacuum and modified atmosphere packaging, and at ambient and refrigeration temperature. Hurdle system designed using natural and non-thermal process are by far efficient than abusive preservation system that lead to deterioration and instability of food products.

\section{Conclusion}

The growing health concern on methods of food preservation, food additives and emerging antibiotic resistant food borne pathogens forced the scientific world to look for an efficient technology of food preservation. In this regard, natural preservation has given due attention using metabolites from microbes, plants and animals. The application of natural preservatives has exhaustively been studied for efficient preservation of different food stuffs without adverse effect on the organoleptic properties and nutritional quality of the product, towards meeting consumer interest for safe, stable and minimally processed products. The preservative efficacy of natural preservatives is much pronounced when they are applied in combination than individually added to the product. Therefore, it is paramount to focus on the formulation of series of hurdle consisting of more natural preservatives with fewer chemical preservatives, while considering the intrinsic and extrinsic properties of the product.

It is highly expected that the application of natural preservatives will likely increase in the future with alarmingly increasing consumer demand for organic, fresh and prolonged shelf life food products. In this regard, Sophisticated investigation on finding novel natural preservatives and hurdle system is highly demanding. Hence, related research must take molecular aspect of organic preservatives and their effect on gene expression in to account to address the safety risks after consumption of the preservatives.

\section{References}

1. Abdou, A., M., Higashiguchi, S., Aboueleinin, A., M., Kim, M. \& Ibrahim, H., R. (2007), “Antimicrobial Peptide Derived from Hen Egg Lysozyme with Inhibitory Effect Against Bacillus Species", Food Control, 18, 173-178.

2. Abee, T., Krockel, L., \& Colin Hill, C. (1995), "Bacteriocins: Modes of Action and Potentials in Food Preservation and Control of Food Poisoning”, International Journal of Food Microbiology, 28, 169-185.

3. Adoui F, Boughellout H, Benyahia-Krid FA, Aissaoui-Zitoun O, Charrad N et al. (2018) "Assessment of Antimicrobial Effect of the Artemisia herba-alba Aqueous Extract as a Preservative in Algerian Traditional Fresh Cheese", J Food Microbiol Saf Hyg, 3, 129.

4. Arques, J., L., Rodriguez, E., Nunez., M. \& Medina, M. (2011), "Combined Effect of Reuterin and Lactic Acid Bacteria Bacteriocins on The Inactivation of Food Borne Pathogens in Milk”, Food Control, 22, 457461.

5. Aymerich, T., Garriga, M., Ylla, J., Vallier, J.,. Monfort , J., M. \& Hugas, M. (2000), “Application of Enterocins as Bio-preservatives against Listeria innocua in Meat Products", Journal of Food Protection, 63(6),721-726.

6. Backialakshmi, S., Meenakshi, R., N., Saranya, A., Jebil, M., S., Krishna, A., R., Krishna, J., S \& Ramasamy, S. (2015), "Bio-preservation of Fresh Orange Juice Using Antilisterial Bacteriocins101 and Antilisterial Bacteriocin103 Purified from Leuconostoc mesenteroides", J Food Process Technol, 6: 479483.

7. Barbosa, A., A., T., Mantovani, H., C. \& Sona Jain, S. (2017), "Bacteriocins from Lactic Acid Bacteria and Their Potential in The Preservation of Fruit Products, Critical Reviews in Biotechnology, DOI: 10.1080/07388551.2016.1262323.

8. Bastos, M. C. F. \& Ceotto, H. (2011), "Bacterial Antimicrobial Peptides and Food Preservation", Natural Antimicrobials in Food Safety and Quality, CAB International, 62-76.

9. Behnam, S., Anvari, M., Rezaei, M., Soltanian, S. \& Safari, R. (2015), "Effect of Nisin as A Biopreservative Agent on Quality and Shelf Life of Vacuum Packaged Rainbow Trout (Oncorhynchus mykiss) Stored At $4{ }^{\circ}$ C", J Food Sci Technol, 52(4):2184-2192.

10. Bilej, M. (2015), "Mucosal Immunity in Invertebrates", Mucosal Immunology, http://dx.doi.org/10.1016/B978-0-12-415847-4.00009-4.

11. Bouttefroy, A. \& Milliere, J. (2000), "Nisin-Curvaticin 13 Combinations for Avoiding the Regrowth of Bacteriocin Resistant Cells of Listeria monocytogenes ATCC 15313", International Journal of Food Microbiology, 62 ,65-75.

12. Brown, C., A., Wang, B. \& Oh, J. (2008), "Antimicrobial Activity of Lactoferrin against Foodborne 
Pathogenic Bacteria Incorporated into Edible Chitosan Film", Journal of Food Protection, 71 (2) 319-324.

13. Budde, B., B., Hornbaek, T., Jacobsen T., Barkholt, V., Koch, A., G. (2003), "Leuconostoc carnosum 4010 has the potential for use as protective culture for vacuum- packed meats: culture isolation, bacteriocin identification, and meat application experiments", International Journal of Food Microbiology, 83, 171-184.

14. Burgos, M., J., G., Pulido, R., P., P., Aguayo, M., D., C., L., Gálvez, A. \& Lucas, R. (2014), “The Cyclic Antibacterial Peptide Enterocin AS-48: Isolation, Mode of Action, and Possible Food Applications", Int. J. Mol. Sci., 15, 22706-22727.

15. Castellano, P. \& Vignolo, G. (2006), "Inhibition of Listeria innocua and Brochothrix thermosphacta in Vacuum-Packaged Meat by Addition of Bacteriocinogenic Lactobacillus curvatus CRL705 and Its Bacteriocins", Letters in Applied Microbiology, 43,194-199.

16. Cegielska-Radziejewska, R., Lesnierowski, G. \& Kijowski, J. (2009), “Antibacterial Activity of Hen Egg White Lysozyme Modified by Thermochemical Technique", Eur Food Res Technol, 228:841-845.

17. Colak, H., Hampikyan, H., Bingol, E., B. \& Aksu, H. (2008), "The Effect of Nisin and Bovine Lactoferrin on the Microbiological Quality OF Turkish-Style Meatball (Tekirdag `Köfte)”, Journal of Food Safety, 28, 355-375.

18. Da Costa, R., J., Voloski, F., L., S., Mondadori, R., G., Duval, E., D., \& Fiorentini, A., M. (2019), "Preservation of Meat Products with Bacteriocins Produced by Lactic Acid Bacteria Isolated from Meat", Journal of Food Quality, dio.org/10.1155/2019/472610.

19. de Carvalho, A., A., T., Mantovani, H., C. \& Vanetti, M., C., D. (2007), "Bactericidal Effect of Bovicin HC5 and Nisin Against Clostridium tyrobutyricum Isolated from Spoiled Mango Pulp", Letters in Applied Microbiology, 45, 68-74.

20. de Carvalho, A., A., T., Costa, E., D., Mantovani H., C. \& Vanetti, M., C., D. (2006), "Effect of Bovicin HC5 on Growth and Spore Germination of Bacillus cereus and Bacillus thuringiensis Isolated from Spoiled Mango Pulp", Journal of Applied Microbiology, 102, 1000-1009.

21. Deegan, L., H., Cotter, P., D., Hill, C. \& Ross, P. (2006), "Bacteriocins: Biologicals Tools for Biopreservation and Shelf-life Extension”, International Dairy Journal, 16: 1058-1071.

22. Dimitrijevi, M., Grkovic, N., Boškovic, M., Baltic, M., Z., Dojcinovic, S., Karabasil, N., D., Vasilev, D. \& Teodorovic, V. (2018), "Inhibition of Listeria monocytogenes Growth on Vacuum Packaged Rainbow Trout (Oncorhynchus mykiss) with Carvacrol and Eugenol", Journal of Food Safety, 39, 1-6.

23. Duran, A. \& Kahve, H., I. (2017), "The Use of Lactoferrin in Food Industry”, Academic Journal of Science, 7(02):89-94.

24. Einarsson, H., R. \& Lauzon, H., L. (1995), "Biopreservation of Brined Shrimp (Pandalus borealis) by Bacteriocins from Lactic Acid Bacteria", Applied and Environmental Microbiology, 61(2), 669-676.

25. Faiza, A., Aziza, B., F., Halima, B., Ouarda, A., Norhane, C., Maroua, H., \& Nasereddine, Z., M. (2018), "Assessment of Antimicrobial effect of the Artemisia herba-alba Aqueous Extract as a Preservatives in Algerian Traditional Fresh Cheese", Journal of Food: Microbiology, Safety, Hygiene,3, 129. Doi/10.4172/2476-2059.10000129.

26. Fernades, J., C., Tavaria, F., K., Soares, J., C., Romas, O., S, Monteiro, M., J., Pintado, M., E. \& Malcata, F., X. (2008), "Antimicrobial Effect of Chitosan and Chitooligosaccharides, Upon Staphylococcus aureus and Escherichia coli, in Food Model System", Food Microbiology, 25, 922-928

27. Friedman, M. \& Juneja, V., K. (2010), "Review of Antimicrobial and Antioxidative Activities of Chitosans in Food", Journal of Food Protection, 73 (9), 1737-1761.

28. Friedman, M., Henika, P., R. \& Mandrell, R., E. (2002), "Bactericidal Activities of Plant Essential Oils and Some of Their Isolated Constituents against Campylobacter jejuni, Escherichia coli, Listeria monocytogenes, and Salmonella enterica", Journal of Food Protection, 65 (10), 1545-1560.

29. G'alvez, A., L'opez, R., L., \& Abriouel, H. (2008), "Application of Bacteriocins in the Control of Foodborne Pathogenic and Spoilage Bacteria”, Critical Reviews in Biotechnology, 28, 125-152.

30. Gálvez, A., Burgos, M., J., G., López, R., L. \& Pulido, R., P. (2014), "Food Bio-preservation", SpringerBriefs in Food, Health, and Nutrition, DOI 10.1007/978-1-4939-2029-7_1.

31. Ganz, T. (2003), "Defensins Antimicrobial Peptides of Innate Immunity", Nature Review, doi: $10.1038 /$ nrill 80 .

32. Garc'ia-Bayona, L., Guo, M., S. \& Laub, M., T. (2017), “Contact-dependent killing by Caulobacter crescentus Via Cell Surface-associated, Glycine Zipper Proteins”, Microbiology and Infectious Disease, DOI: $10.7554 /$ eLife.24869.

33. Ghanbari, M. \& Jami, M. (2013), "Lactic Acid Bacteria - R \& D for Food, Health and Livestock Purposes", Open access, http://dx.doi.org/10.5772/50705.

34. Gochev, V., Dobreva, A., Girova, T. \& Stoyanova, A. (2010), “Antimicrobial Activity of Essential Oil from Rosa alba", Biotechnology \& Biotechnological Equipment, 24, 512-515.

35. Grande, M., J., Lucas, R., Valdivia, E., Abriouel, H., Maqueda, M., Omar, N., B., amero, M., M., N. \& Ga ' 
Lvez1, A. (2005), "Stability of Enterocin AS-48 in Fruit and Vegetable Juices", Journal of Food Protection, $\mathbf{6 8}(10), 2005,2085-2094$.

36. Guran, H., S., Oksuztepe, G., Coban, O., E.\& Incili, G., K. (2011), "Influence of Different Essential Oils on Refrigerated Fish Patties Produced from Bonito Fish (Sarda sarda Bloch, 1793)", Food Analysis, Food Quality and Nutrition, 33(1),37-44.

37. Gutierrez, J., Barry-Ryan, C. \& Bourke, P. (2009), “Antimicrobial Activity of Plant Essential Oils Using Food Model Media: Efficacy, Synergistic Potential and Interactions with Food Components". Food Microbiol., 26, 142-150.

38. Gyawali, R. \& Ibrahim, S., A. (2014), "Natural Products as Antimicrobial Agents", Food Control, 46, 412429.

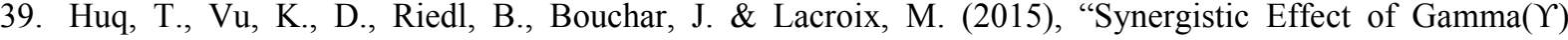
Radiation and Microencapsulated Antimicrobial Against Listeria monocytogenes on Ready-To-Eat (RTE) Meat", Food Microbiology, 46, 507-514.

40. Jacobsen, T., Budde, B., B. \& Koch, A., G. (2003)," Application of Leuconostoc carnosum for biopreservation of cooked meat products" Journal of Applied Microbiology, 95, 242-249.

41. Jay, J., M. (2000), “Modern Food Microbiology” Aspen Publishers, Inc.,60 ${ }^{\text {th }}$ Edition,pp, 625.

42. Je, J. \& Kim, S. (2006), "Chitosan Derivatives Killed Bacteria by Disrupting the Outer and Inner Membrane", J. Agric. Food Chem., 54, 6629-6633.

43. Jeevaratnam, K., Jamuna, M. \& Bawa, A., S. (2005), "Biological preservation of Food-Bacteriocins of Lactic acid Bacteria", International Journal of Biotechnology, 4, 446-454.

44. Juneja, V., K., Dwivedi, H., P. \& Yan, X. (2012), "Novel Natural Food Antimicrobials" Annu. Rev. Food Sci. Technol., 3:381-403.

45. Kalschne, D., L., Geitenes, S., Veit, M., R., Sarmento, C, M., P. \& Colla, E. (2014), "Growth Inhibition of Lactic Acid Bacteria in Ham by Nisin: A Model Approach", Meat Science,98, 744-752.

46. Karpiński, T., M., \& Szkaradkiewicz, A. K. (2013), "Characteristic of Bacteriocins and their Application”, Polish Journal of Microbiology,62(3), 223-235.

47. Katla, T., Moretro, T., Aasen, I., M., Holck, A., Axelsson, L. \& Naterstad, K. (2001), "Inhibition of Listeria monocytogenes in Cold Smoked Salmon by Addition of Sakacin P and/or Live Lactobacillus sakei Cultures", Food Microbiology, 18,431-439.

48. Khan, H., Flint, S. \& YU, P. (2010), 'Enterocins in Food preservation', International Journal of Food Microbiology, 14,1-10.

49. Komitopoulou, E., Boziaris, I., S., Davies, E., A., Delves-Broughton, J. \& Adams, M., R. (1999), “Alicyclobacillus acidoterrestris in Fruit Juices and Its Control by Nisin”, International Journal of Food Science Technology, 34, 81-85.

50. Kongo, M. (2013), "Lactic Acid Bacteria - R \& D for Food, Health and Livestock Purposes", open access, http://dx.doi.org/10.5772/55937.

51. Koo, O., K., Kim, S., M. \& Sun-Hee Kang, S. (2015), "Antimicrobial Potential of Leuconostoc species against E. coli O157:H7 in Ground Meat", J Korean Soc Appl Biol Che, Springer, DOI 10.1007/s13765015-0112-0.

52. Kouakou, P., Ghalfi, H., Destain, J., Duboisdauphin, R., Evard, P. \& Thonart, P. (2008), "Enhancing the Antilisterial Effect of Lactobacillus carvatus CWBI-B28 in Pork Meat and Cocultures by Limiting Bacteriocin Degradation", Meat Science, 80,6 40-648.

53. Kykkidou, S., Pournis, N., Kostoula, O., K. \& Savvaidis, I, N. (2007), "Effect of Treatment with Nisin on the Microbial Flora and Sensory Properties of a Greek Soft Acid-curd Cheese Stored Aerobically at $4^{\circ} \mathrm{C}$ ", International Dairy Journal, 17, 1254-1258.

54. Leverentz, B., Conway, W., S., Camp, M., J., Janisiewicz, W., J., Abuladze, A., Yang, M., Saftner, R. \& Sulakvelidze, A. (2003), "Biocontrol of Listeria monocytogenes on Fresh-Cut Produce by Treatment with Lytic Bacteriophages and a Bacteriocin", Applied and Environmental Microbiology, 68(8), 4519-4526.

55. Lineback, D., R., Pirlet, A., Kamp, J., V., D. \& Wood, R. (2009), “Globalization, Food Safety Issues \& Role of International Standards”, Quality Assurance and Safety of Crops \& Foods, ISSN 1757-8361, 2009 Blackwell Publishing, doi:10.1111/j.1757-837X.2009.00005. x.

56. Lucas, R., Grande, M., J., Abriouel, H., Maqueda, M., Omar, N., B., Valdivia, E., Martinez-Canamero, M. \& Galvez, A. (2006), "Application of A Broad Spectrum Bacteriocin Enterocin AS-48 to Inhibit Bacillus coagulansi n Canned Fruits and Vegetables Food", Food and Chemical Toxicology, 44, 1774-178.

57. Mahendra Pal, M., Abiy S., Wondu M., Amit M. Barot, A., M., T., Pinto, S., V. \& Prajapati, J., P. (2017), "Hurdle Technology : A novel approach for Food Preservation", Beverage \& Food World, 44(1),20-26,

58. Mani, A. (2018), "Food Preservation by Fermentation and Fermented food products", International Journal of Academic Research \& Development, 1, 51-57.

59. Martinez- Cuesta, M., C., Bengoechea, J., Bustos, I., Rodriguez, B., Requena, T. \& Pelaez, C. (2010), 
"Control of Late Blowing in Cheese by Adding Lacticin 3147- Producing Lactococcus lactis IFPL 3593 to the Starter", International Dairy Journal, 20, 18-24.

60. Molinos, A., C., Abriouel, H., Omar, N., B., Lucas, R., Valdivia, E. \& Galvez1, A. (2008), "Inactivation of Listeria monocytogenes in Raw Fruits by Enterocin AS-48”, Journal of Food Protection, 71(12),2460-2467

61. Molinos, C., A., Abriouel, H., Lo 'pez, R., L., Omar, N., B., Valdivia, E. \& Galvez1, A. (2009b),"Enhanced Activity of Enterocin AS-48 in Combination with Essential Oils Natural Bioactive Compounds and Chemical Preservatives Against Listeria monocytogenes in Ready-to-eat Salad", Food and Chemical Toxicology, 47,2216-2223.

62. Molinos, C., A., Lo 'pez, R., L., Abriouel, H., Omar, N., B., Valdivia, E. \& Galvez1, A. (2009a), "Inhibition of Salmonella enterica Cells in Deli-Type Salad by Enterocin AS-48 in Combination with Other Antimicrobials", Probiotics \& Antimicro. Prot., 1, 85-90.

63. Morga, S., M., Galvin, M., Ross, R., P. \& Hill, C. (2001), "Evaluation of a Spray-dried lacticin 3147 Powder for the Control of Listeria monocytogenes and Bacillus cereus in a Range of Food Systems", Letters in Applied Microbiology, 33, 387-391.

64. Mostafa, A., A., Al-Askar, A., A., Almaary, K., S., Dawoud, T., M., Sholkamy, E., N. \& Bakri, M., M. (2018), "Antimicrobial Activity of Some Plant Extracts Against Bacterial Strains Causing Food Poisoning Diseases", Saudi Journal of Biological Sciences, 25, 361-366.

65. Munoz, A., Ananou, S., Galvez, A., Martinez-Bueno, M., Rodriguez, A., Maquede, M., \& Valdivia., E. (2007), "Inhibition of Staphylococcus aureus in Dairy Products by Enterocin AS-48 Produced in In Situ and Ex Situ: Bactericidal Synergism with Heat”, International Dairy Journal, 17, 760-769.

66. Munoz, A., Ananou, S., Galvez, A., Martinez-Bueno, M., Rodriguez, A., Maqueda, M. \& Valdivia, E. (2007), "Inhibition of Staphylococcus aureus in Dairy Products by Enterocin AS-48 Produced in Situ ex Situ: Bacteriocin Synergism with Heat”, International Dairy Journal, 17, 760-769.

67. Murdock, C., A., Cleveland, J., Matthews K., R. \& Chikindas M., L. (2006), "The synergistic effect of nisin and lactoferrin on the inhibition of Listeria monocytogenes and Escherichia coli O157:H7', The Society for Applied Microbiology, Letters in Applied Microbiology, 44, 255-261.

68. Narsaia, K., Wilson, R., A., Gokul, K., Mandge, H., M., Jha, S., N., Bhadwal, S., Anurag, R., K., Malik, R., K. \& Vij, S. (2014), "Effect of Bacteriocin Alginate Coating on Shelf life of Minimally Processed Papaya (Carica papaya L.” Postharvest Biology Technology, 100, 212-218.

69. Nath, S., Chowdhury, S., Dora, P., K., C. \& Sarkar, S. (2014), "Role of Bio-preservation In Improving Food Safety and Storage", Int. Journal of Engineering Research and Applications, 3, 26-32.

70. Nazir, F., Salim, R., Yousf, N., Bashir, M., Naik, H., R.\& Hussain, S., Z. (2017), "Natural Antimicrobials for Food Preservation", Journal of Pharmacognosy and Phytochemistry, 6(6): 2078-2082.

71. Nieto-Lozano, J., C., Regeuera-Useros, J., I., Pelaez-Martinez, M., D., C. \& Torre, A., H., D., L. (2006), "Effect of A Bacteriocin Produced by Pediococcus acidilactici against Listeria monocytogenes and Clostridium perfringens on Spanish Raw Meat", Meat Science, 72, 57-61.

72. Olandunjoye, A., O., Singh, S. \& Ijabadeniyi, O., A. (2016), "Inactivation of Listeria monocytogenes ATCC 7644 on Fresh-cut Using Nisin in Combination with Organic Salts" Brazilian Journal of Microbiology, 47, 757-763.

73. Oshima, S., Hirano, A., Kamikado, H., Nishimura, J., Kawai, Y.\& Saito, T. (2014), "Nisin A extends the shelf life of high-fat chilled dairy dessert, a milk-based pudding", Journal of Applied Microbiology, 116, $1218-1228$.

74. Pal, M., Azeb, G, Tilaye, S., Mukarim, A., \& Olga, K.(2015). "The Role of Bacteriocin as Food Preservative", Beverage \& Food World, 42(1), 28-35.

75. Parada, J., L., Caron, C., R., Medeiros, A., B., P. \& Soccol, C., R. (2007). "Bacteriocins from Lactic Acid Bacteria: Purification, Properties and Use as Bio-preservatives". Brazilian Archives of Biology and Technology, 50(3), 521-542.

76. Pilet, M. \& Leroi, F. (2011), “Applications of Protective Cultures, Bacteriocins and Bacteriophages in Fresh Seafood and Seafood Products", Woodhead Publishing Limited, pp, 21.

77. Pimentel-Filho, N., D., J., Mantovani, H., C., de Carvalho, A., F., Dias, R., S. \& Vanetti, M., C., D. (2013), "Efficacy of Bovicin HC5 and Nisin Combination Against Listeria monocytogenes and Staphylococcus aureus in Fresh Cheese", International Journal of Food Science and Technology, 49, 416-422.

78. Potter, R., Hanssen, L., T. \& Gill, T., A. (2005), "Inhibition of Food Borne Bacteria by Native and Modified Protamine: Importance of Electrostatic Interactions", International Journal of Food Microbiology, 103, 23-34.

79. Ray, R., C. \& Joshi, V., K. (2014), "Fermented Foods: Past, Present and Future", DOI: 10.13140/2.1.1849.8241.

80. Renye, J., A., Jr \& Somkuti, G., A. (2015), "Bacteriocins of Food Grade Lactic Acid Bacteria in Hurdle Technology for Milk and Dairy Products" Emerging Dairy Processing Technologies: Opportunities for the 
Dairy Industry, First Edition, John Wiley \& Sons, Ltd pp., 40.

81. Ribeiro, S., C., Ross, R., P., Stanton, C. \& Silva, C., C., G. (2017), "Characterization and Application of Antilisterial Enterocins on Model Fresh Cheese", Journal of Food Protection, 80, (8),1303-1316.

82. Ribeiroa, S. C., O'Connorb, P., M., R. Rossc, R., P., Stantonb. \& Silva, C., C., G., (2016), “An anti-listerial Lactococcus lactis strain isolated from Azorean Pico cheese produces lacticin 481", International Dairy Journal, doi: 10.1016/j.idairyj.2016.07.017.

83. Rivas, F., P., Castrol, M., P., Vallejo, M., Marguet, E. \& Campos, C., A., (), "Sakasin Q Produced by Lactobacillus carvatus ACU-1: Functionality Characteristics and Antilisterial Activity on Cooked Meat Surface", Meat Science, 97, 475-479.

84. Saeed, M., Yasmin, I., Khan, M., I., Nadeem, M., Shabbir, M., A., \& Azam, M. (2016), "Herbs and Spices as a Potential Antimicrobial Agents for Food Application”, Pak. J. Food Sci., 26(3), 153-160.

85. Salem, A., M. (2012), "Bio-Preservation Challenge for Shelf-Life and Safety Improvement of Minced Beef', Global Journal of Biotechnology \& Biochemistry 7 (2): 50-60.

86. Schillinger, U., Becker, B., Vignolo, G. \& Holzapfel, W., H. (2001), "Efficacy of Nisin in Combination with Protective Cultures Against Listeria monocytogenes Scott A Tofu", International Journal of Food Microbiology ,71, 59-168.

87. Shashikumar, C., S., S. \& Puranik, D., B. (2011), "Study on Use of Lactoferrin for the Biopreservation of Paneer", Tropical Agricultural Research, 23 (1), 70 - 76.

88. Shin, S., Y., Bajpai, V., K., Kim, H., R. \& Kang, S., C. (2007), "Antimicrobial Activity of Bioconverted eicosapentaenoic (EPA) and Docosahexaenoic Acid (DHA) Food borne Pathogenic Bacteria”, International Journal of Food Microbiology, 113, 233-236.

89. Silva, C., C., G., Silva, S. P., M. \& Ribeiro, S., C. (2018), “Application of Bacteriocins and Protective Culture in Dairy Food Preservation", Frontiers in Microbiology, 9, 594 dio: 10.3389/fmicb.2018.00594.

90. Singh, V., P., Pathak, V., Nayak, N., K., \& Goswami, M. (2014), "Application of Hurdle Concept in Development and Shelf Life Enhancement of Chicken Lollipop”, Int. J. Cur. Microbiol. App. Sci., 3(1), 355-361

91. Škrinjar, M., M. \& Nevena T. Nemet, N., T. (2009), “Antimicrobial Effects of Spices and Herbs Essential Oils", APTEFF, 40, 1-220.

92. Sobrino-Lopez, A. \& Martin-Belloso, O. (2008), "Use of Nisin and Other Bacteriocins for Preservation of Dairy Products", International Journal of Dairy Journal, 18, 329-343.

93. Thomas, L., Ingram, R., Bevis, H., Davies, A., E., Milne, C. and Delves-Broughton, J. (2002), "Effective Use of Nisin To Control Bacillus and Clostridium Spoilage of a Pasteurized Mashed Potato Product", Journal of Food Protection, 65(10), 580-1585.

94. Tiwari, B., K., Valdramidis, V. P., O’ Donnell, C., P., Muthukumarappan, K., Bourke, P. \& P. J. Cullen, P., J. (2009), "Application of Natural Antimicrobials for Food Preservation”, Journal of Agricultural and Food Chemistry, 57 (14), 5987-6000.

95. Turgis, M., Stotz, V., Dupont, C., Salmieri, S., Khan, R., A. \& Lacroix, M. (2012), "Elimination of Listeria monocytogenes in Sausage Meat by Combination Treatment: Radiation and Radiation Resistant Bacteriocins" Radiation Physics and Chemistry, 81, 1185-118.

96. Ukuku, D., O., Bari, M., L., Kawamoto, S. \& Isshiki, K. (2002), "Use of Hydrogen Peroxide in Combination Nisin, Sodium Lactate, Citric Acid for Reducing Transfer of Bacteria Pathogens from Whole Melon Surfaces to Fresh-cut Pieces", International Journal of Food Microbiology, 104, 225-233.

97. Verma, S., K., Sood, S., K., Saini, R., K. \& Saini, N. (2017), "Pediocin PA-1 Containing Fermented Cheese Whey Reduces Total Viable Count of Raw Buffalo (Bubalis bubalus) Milk”, Food Science and Technology, doi: 10.1016/j.lwt.2017.02.031.

98. Viedma, P., M., Abriouel, H., Omar, N., B., Lopez, R., L. \& Galvez, A. (2010), "Effect of Enterocin EJ97 Geobacillus stearothermophilus Vegetative Cells and Endospores in Canned Food and Beverages", Eur Food Res Technol, 230,513-519.

99. Viedma, P., M., Abriouel, H., Omar, N., B., Lopez, R., L., Valdivia, E. \& Galvez, A., (2009), “Inactivation of Geobacillus stearothermophilus in Canned Food and Coconut Milk Samples by Addition of Enterocin AS-48", Food Microbiology, 26, 289-293.

100. Viedma, P., M., Ercolini, D., Ferrocino, I., Abriouel., H., Omar, N., B., Lopez, R., L. \& Galvez, A. (2010), "Effect of polythene Film Activated with Enterocin EJ97 in Combination with EDTA against Bacillus coagulans", Food Science and Technology, 43, 514-518.

101. Vilcacundo, R., Méndez, P., Reyes, W., Romero, H., Pinto, A. \& Carrillo, W. (2018), “Antibacterial Activity of Hen Egg White Lysozyme Denatured by Thermal and Chemical Treatments", Sci. Pharm., 86, $1-17$.

102. Walker, M. \& Philips, C., A. (2008), "The Effect of Preservatives on Alicyclobacillus acidoterrestris and Propionibacterium cyclohexanicum in Fruit Juice", Food Control, 19, 974-981. 
103. Weiss, A. \& Hammes, W., P. (2006), "Lactic Acid Bacteria as Protective Cultures Against Listeria spp. on Cold-Smoked Salmon”, Eur Food Res Technol, 222, 343-346.

104. Woraprayote, W., Malila, Y., Sorapukdee, S., Swewiwathana, A., Benjakul, S. \& Visessanguan, W. (2016), "Bacteriocin from Lactic Acid Bacteria and Their Applications in Meat and Meat Products", http://dx.doi.org/10.1016/j.meatsci.2016.04.004.

105. Yamazaki, K., Suzuki, M., Kawai, Y., Inoue, N. \& Montville, T. (2003), "Inhibition of Listeria monocytogenes in Cold-Smoked Salmon by Carnobacterium piscicola CS526 Isolated from Frozen Surimi”, Journal of Food Protection,.66 (8),420-1425.

106. Yildirima, Z., Öncülb, N., Yildirima, M. \& Karabiyiklib, Ş. (2016), “Application of Lactococcin Bz and Enterocin Kp Against Listeria monocytogenes in Milk as Bio-preservation Agents", Acta Alimentaria, 45 (4), 486-492.

107. Zeuthen, P. \& Bogh-Sorensen, L. (2003), "Food Preservation Techniques", Woodhead Publishing Limited Abington Hall, Abington Cambridge CB1 6AH England, pp, 578.

108. Zhang, H., Kong, B., Xiong, Y., L. \& X. (2009), "Sun: Antimicrobial Activities of Spice Extracts Against Pathogenic and Spoilage Bacteria in Modified Atmosphere Packaged Fresh Pork and Vacuum Packaged Ham Slices Stored at $4^{\circ}$ C", Meat Sci., 81, 686-692.

109. Zhang, J., Liu, G., Li, P. \& Qu, Y. (2010), "Pediocin 31-1 A novel Meat-borne Bacteriocin and Its Application as Bio-preservatives in Child Stored Tray Packaged Pork Meat", Food Control, 21, 198-202. 